\title{
Reconstructing Common Era relative sea-level change on the Gulf Coast of Florida
}

\author{
Matthew J. Gerlach ${ }^{\mathrm{a}}$, Simon E. Engelhart ${ }^{\mathrm{a}, *}$, Andrew C. Kemp ${ }^{\mathrm{b}}$, Ryan P. Moyer ${ }^{\mathrm{c}}$, \\ Joseph M. Smoak ${ }^{\mathrm{d}}$, Christopher E. Bernhardt ${ }^{\mathrm{e}}$, Niamh Cahill ${ }^{\mathrm{f}}$ \\ a Department of Geosciences, University of Rhode Island, Kingston, RI 02281, USA \\ b Department of Earth and Ocean Sciences, Tufts University, Medford, MA 02155, USA \\ c Florida Fish and Wildlife Conservation Commission, St. Petersburg, FL 33701, USA \\ d Environmental Science, University of South Florida, St. Petersburg, FL 33701, USA \\ e U.S. Geological Survey, Reston, VA 20192, USA \\ ${ }^{\mathrm{f}}$ Department of Biostatistics and Epidemiology, University of Massachusetts Amherst, MA 01003, USA
}

\begin{abstract}
A B S T R A C T
To address a paucity of Common Era data in the Gulf of Mexico, we reconstructed $\sim 1.1 \mathrm{~m}$ of relative sea-level (RSL) rise over the past $\sim 2000$ years at Little Manatee River (Gulf Coast of Florida, USA). We applied a regionalscale foraminiferal transfer function to fossil assemblages preserved in a core of salt-marsh peat and organic silt that was dated using radiocarbon and recognition of pollution, ${ }^{137} \mathrm{Cs}$ and pollen chronohorizons. Our proxy reconstruction was combined with tide-gauge data from four nearby sites spanning 1913-2014 CE. Application of an Errors-in-Variables Integrated Gaussian Process (EIV-IGP) model to the combined proxy and instrumental dataset demonstrates that RSL fell from $\sim 350$ to $100 \mathrm{BCE}$, before rising continuously to present. This initial RSL fall was likely the result of local-scale processes (e.g., silting up of a tidal flat or shallow sub-tidal shoal) as saltmarsh development at the site began. Since $\sim 0 \mathrm{CE}$, we consider the reconstruction to be representative of regional-scale RSL trends. We removed a linear rate of $0.3 \mathrm{~mm} / \mathrm{yr}$ from the RSL record using the EIV-IGP model to estimate climate-driven sea-level trends and to facilitate comparison among sites. This analysis demonstrates that since $\sim 0 \mathrm{CE}$ sea level did not deviate significantly from zero until accelerating continuously from $\sim 1500 \mathrm{CE}$ to present. Sea level was rising at $1.33 \mathrm{~mm} / \mathrm{yr}$ in $1900 \mathrm{CE}$ and accelerated until $2014 \mathrm{CE}$ when a rate of $2.02 \mathrm{~mm} / \mathrm{yr}$ was attained, which is the fastest, century-scale trend in the $\sim 2000$-year record. Comparison to existing reconstructions from the Gulf coast of Louisiana and the Atlantic coast of northern Florida reveal similar sea-level histories at all three sites. We explored the influence of compaction and fluvial processes on our reconstruction and concluded that compaction was likely insignificant. Fluvial processes were also likely insignificant, but further proxy evidence is needed to fully test this hypothesis. Our results indicate that no significant Common Era sea-level changes took place on the Gulf and southeastern Atlantic U.S. coasts until the onset of modern sea-level rise in the late 19th century.
\end{abstract}

\section{Introduction}

The Atlantic coast of North America has a high density and wide geographic distribution of Common Era relative sea-level (RSL) reconstructions produced (primarily) from proxies preserved in sequences of salt-marsh sediment such as foraminifera (e.g., Gehrels et al., 2005; Kemp et al., 2013). This network of reconstructions demonstrates that local and regional-scale sea level departed from a linear trend during the past $\sim 2000$ years (e.g., Kemp et al., 2015). The magnitude, geographic pattern and timing of these coastal RSL trends provide unique insight into the processes that caused RSL to vary on multi-decadal to millennial timescales (e.g., Kopp et al., 2016). While Common Era RSL change in the North Atlantic Ocean is driven principally by glacio-isostatic adjustment (GIA; e.g., Peltier, 1996), at regional scales it is also sensitive to the fingerprint of melting of land-based ice in Greenland (e.g., Hay et al., 2014; Mitrovica et al., 2011) and dynamic trends occurring from the redistribution of existing ocean mass by persistent shifts in ocean and/or atmospheric circulation (e.g., Ezer et al., 2013; Levermann et al., 2005; here termed ocean dynamics). The paleo perspective on these processes that is afforded by RSL reconstructions helps to constrain physical models and future predictions on the spatial and temporal timescales that are the focus of coastal planning (e.g., Nicholls et al., 2014). In contrast, there is

\footnotetext{
* Corresponding author at: Department of Geosciences, 336 Woodward Hall, University of Rhode Island, Kingston, RI 02881, USA

E-mail address: engelhart@uri.edu (S.E. Engelhart).
} 
a scarcity of detailed RSL reconstructions from the Gulf of Mexico (e.g., González and Törnqvist, 2009). The Gulf of Mexico is insensitive to ocean dynamic trends caused by forcings that likely characterized the Common Era (Yin, 2012). In addition, the Gulf of Mexico experiences a sea-level trend closer to the global mean than sites in (for example) New England or the U.S. mid-Atlantic because of the spatial fingerprint (e.g., Clark and Lingle, 1977) of Greenland ice sheet melt (e.g., Kopp et al., 2010). Therefore, the (dis)similarity between Common Era RSL trends along the Gulf of Mexico and Atlantic Ocean coasts can offer valuable insight into the causes of regional-scale sea-level change. Our goal is to address the current imbalance in the distribution of Common Era RSL reconstructions and to provide insight into the driving mechanisms of RSL change by producing a new record from salt-marsh sediment in the Gulf of Mexico.

High salt-marsh environments accumulate peat to maintain their elevation in the tidal frame (e.g., Bloom, 1964; Morris et al., 2002). Through this response, the accommodation space created by RSL rise is filled with in-situ peat, which is a valuable sedimentary archive of Common Era RSL change (e.g., Gehrels et al., 2002; Törnqvist et al., 2004; Varekamp et al., 1992). Using foraminifera preserved in the buried salt-marsh peat and a transfer function approach, RSL can be reconstructed with a precision (typically $\pm 10-15 \%$ of tidal range) that enables the identification of small-scale (order of $10 \mathrm{~s}$ of centimeters and decades) variability in RSL (e.g., Barlow et al., 2013; Gehrels et al., 2012), which is the expected magnitude of changes caused, for example, by ocean dynamics (Yin, 2012). Proxy-based reconstructions can be combined with tide-gauge measurements to create a composite RSL history and further reduce uncertainty (e.g., Donnelly et al., 2004; see discussion in Kemp et al., in press).

We reconstructed $\sim 2000$ years of regional-scale RSL change on the Gulf Coast of Florida using foraminifera preserved in a dated core of saltmarsh peat from Little Manatee River (eastern Tampa Bay; Fig. 1). This proxy reconstruction was merged with regional tide-gauge measurements, covering the period 1913-2014 CE, to create a combined proxyinstrumental RSL record. After correction for GIA, we compare our findings to existing Common Era sea-level reconstructions on the Gulf of Mexico coast in Louisiana (González and Törnqvist, 2009) and on the Atlantic Ocean coast of northern Florida (Kemp et al., 2014). This analysis enables us to answer two research questions: (1) did RSL depart from a stable mean prior to $\sim 1850 \mathrm{CE}$ in the Gulf of Mexico? And (2) can inferences be drawn about the processes driving regional RSL trends on multi-decadal to millennial timescales through comparison of RSL trends in the Gulf of Mexico and along the U.S. southeastern Atlantic coast?

\section{Study area}

We selected the west coast of Florida as our study area within the Gulf of Mexico (Fig. 1A) for two reasons. Firstly, this region includes expansive salt marshes in contrast to more arid coastlines elsewhere in the Gulf of Mexico (e.g. Texas) where these environments are rare and RSL reconstructions need to be derived from alternative proxies such as microbial mats (e.g., Livsey and Simms, 2013) that have relatively large vertical uncertainties. Secondly, this region is sufficiently distant from the Mississippi Delta to minimize the contribution to RSL change from ongoing subsidence of the delta (e.g., Wolstencroft et al., 2014; Yu et al., 2012) and reshaping of the geoid by the time-evolving configuration and mass of the delta (e.g., Dalca et al., 2013).

Tampa Bay is a shallow (mean depth $<4 \mathrm{~m}$ ), siliciclastic-dominated embayment (Fig. 1B) that experiences a humid, sub-tropical climate with an average annual air temperature of $\sim 23^{\circ} \mathrm{C}$ and average precipitation of $\sim 1250 \mathrm{~mm} / \mathrm{yr}$. The estuary lies near the center of the Jurassic-aged Florida Platform (Hine et al., 2003) overlying an Oligocene-aged karstic sub-basin that collapsed in the mid-Miocene due to deep-dissolution (Brooks and Doyle, 1998; Hine et al., 2009; Morrison and Yates, 2011). Anthropogenic alteration including dredge and fill, removal of wetlands and groundwater withdrawal associated with the urbanization of the communities surrounding Tampa Bay has caused degradation of hydrological and ecological systems within the estuary (Morrison and Yates, 2011). Therefore, we carefully chose sites to minimize these impacts.
Our study site in the Little Manatee River estuary (Fig. 1D) was selected because our coring efforts at salt marshes throughout Tampa Bay and Charlotte Harbor showed that it had a thick and continuous sequence of high salt-marsh peat that was likely to yield a long and detailed RSL reconstruction. The site currently supports salt-marsh and mangrove ecosystems, which is typical of brackish, tidal rivers in the sub-tropical climate of west-central Florida (U.S. Fish and Wildlife Service, 1999). Rhizophora mangle (red mangrove) trees line the perimeter of the saltmarsh platform and banks of tidal channels at elevations close to mean tide level (MTL). The salt-marsh platform supports a near-monospecific, peat-forming community of Juncus roemerianus (black needle rush) at elevations from MTL to mean higher high water (MHHW). Occasional stands of Acrostichum aureum (golden leather fern) are also present. Due to encroachment of urban development (e.g., housing) on upland margins, salt marshes are currently restricted to platform-type morphologies that rarely attain elevations above MHHW in the Little Manatee River (and similar estuaries discharging into Tampa Bay). Recent (and ongoing) northward migration of mangrove forests into areas previously occupied solely by salt marshes likely occurred in response to a reduced frequency of freeze days (e.g., Osland et al., 2013; Saintilan et al., 2014). Therefore, the establishment of mangroves in the Little Manatee River was likely a recent event (Krauss et al., 2011; Smith et al., 2013) and for most of the Common Era the site was a salt marsh. Our stratigraphic investigations confirmed this assumption since no mangrove peat was found in any of the exploratory cores that we described. Quasi-monthly surface-water testing since $1974 \mathrm{CE}$ shows that close to the coring site, the Little Manatee River has an average salinity of $\sim 13 \%$ (Tampa Bay Water Atlas sampling station 112). At the nearby Little Manatee River tide gauge (NOAA station 8726436; Fig. 1D), the reported mixed, semi-diurnal tidal regime has a great diurnal tidal range (defined by NOAA as mean lower low water, MLLW, to MHHW) of $0.60 \mathrm{~m}$ (Table 1). This tide gauge was operational only from December 1978 to March 1979 because its purpose was to calculate tidal datums rather than to measure long-term RSL trends (the water-level measurements are not available from NOAA).

We collected surface sediment samples at the Little Manatee River site and at four sites in Charlotte Harbor ( $~ 90 \mathrm{~km}$ south of Tampa Bay; Fig. 1C) to characterize the modern, observable relationship between assemblages of foraminifera and tidal elevation (Table 2). The morphology of the Charlotte Harbor sites and their zonation of plants was the same as at Little Manatee River, which is characteristic of the wider study region. The great diurnal tide range at each site within Charlotte Harbor was $0.61 \mathrm{~m}$, as reported for the Harbour Heights tide gauge (NOAA station number 8725791; Fig. 1E; Table 1). This tide gauge operated from December 1977 to March 1978 in order to measure tidal datums rather than RSL trends (the water-level measurements are not available from NOAA).

Long-term tide-gauge measurements from Key West (since $1913 \mathrm{CE}$; NOAA station number 8724580), St. Petersburg (since 1947 CE; NOAA station number 8726520), Fort Myers (since $1965 \mathrm{CE}$; NOAA station number 8725520) and Naples (since $1965 \mathrm{CE}$; NOAA station number 8725110) provide observations of historic RSL change along the Gulf coast of Florida (Fig. 2). We downloaded annual-average data (up to and including 2014 CE) for these four stations from the Permanent Service for Mean Sea Level (http://www.psmsl.org; Holgate et al., 2013).

\section{Methods}

\subsection{Modern training set of salt-marsh foraminifera}

Foraminifera are sea-level indicators because their distribution in salt marshes and mangroves is controlled principally by the frequency and duration of tidal inundation, which is a function of elevation (e.g., Horton and Edwards, 2006; Scott and Medioli, 1978). The relationship of foraminifera to elevation is established empirically from a modern training set of surface sediment samples. This observable, modern relationship is assumed to be applicable to analogous assemblages of foraminifera preserved in buried sediment. Consequently, the tidal elevation at which a fossil sediment sample originally accumulated (termed Paleomarsh 

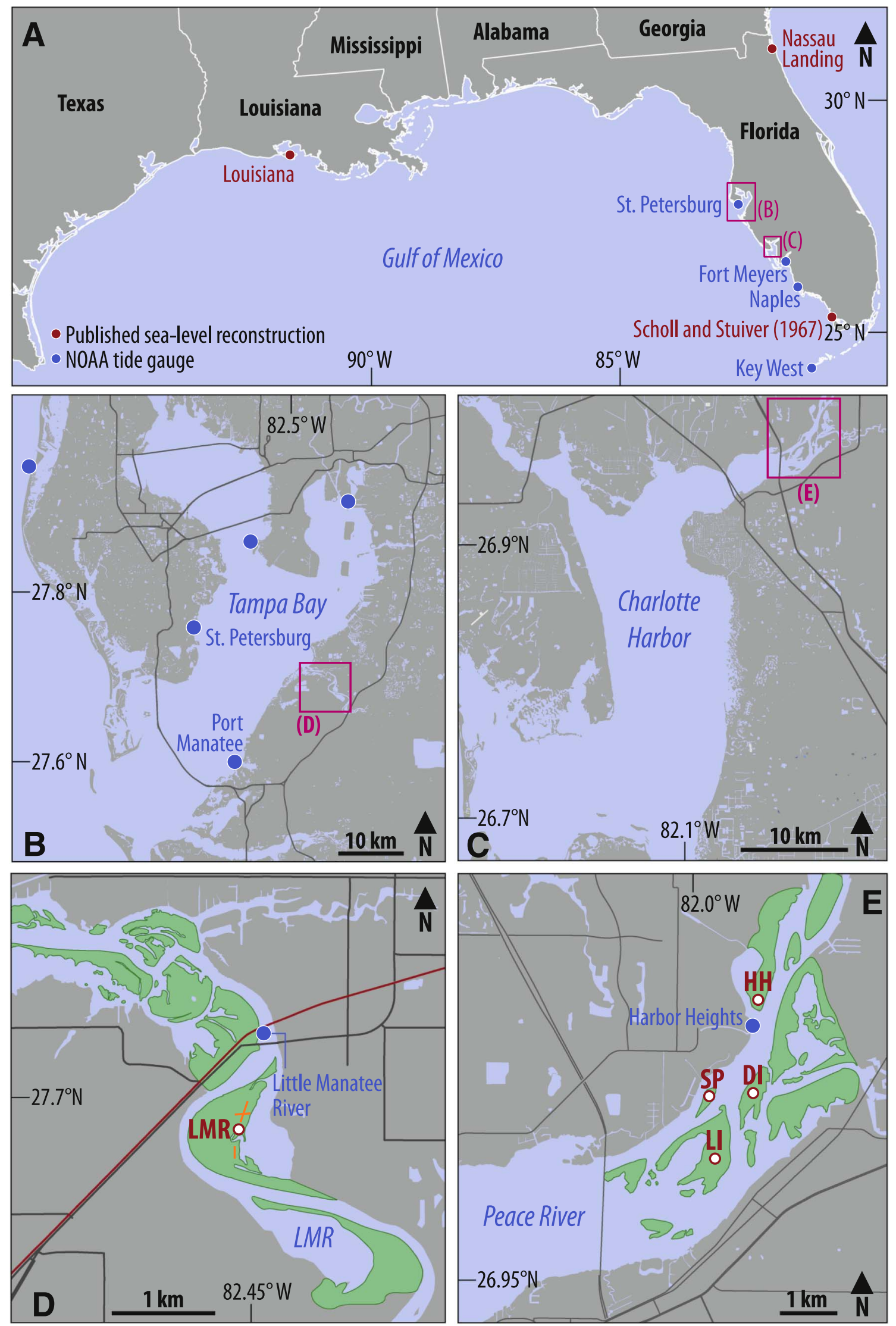

Upland $\square$ Open water

- Salt marsh / Mangrove

Principal road — Railway

Coring transect

O Modern transect $\bullet$ NOAA tide-gauge/tidal benchmark 


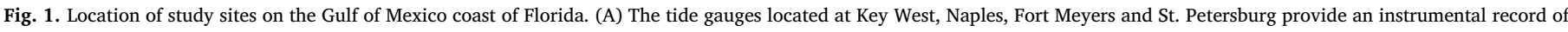

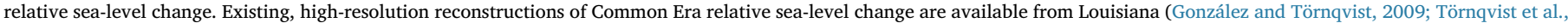

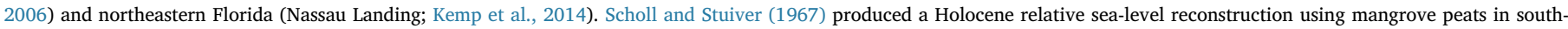

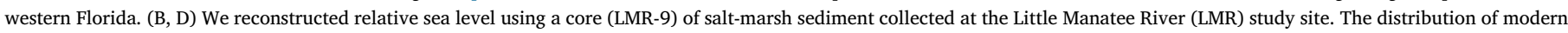

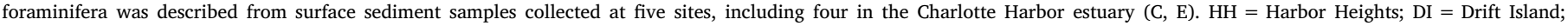
$\mathrm{SP}=$ Sand Point; LI = Long Island.

Elevation; PME) is estimated from the foraminifera preserved in it. In the absence of an existing modern training set for our study area, we developed a regional-scale training set of modern foraminifera from five salt marshes in the Tampa Bay (at our core site in Little Manatee River) and Charlotte Harbor estuaries (Fig. 1D and E). This sampling regime captured the ecological and geomorphological spectrum of salt marshes on the central Gulf Coast of Florida to ensure that the modern dataset included natural variability in foraminiferal populations.

At each of the five modern salt marshes, we collected undisturbed, surface $(0-1 \mathrm{~cm})$ sediment samples at regular elevation changes along transects across the prevailing elevational and environmental gradient. This sampling regime inherently assumes that there is no significant infaunal population of foraminifera. In the southeastern United States, several studies from Juncus roemerianus-dominated salt marshes identified live foraminifera at depths of tens of centimeters below the surface (e.g., Goldstein and Harben, 1993; Goldstein and Watkins, 1998, 1999). However, Culver and Horton (2005) demonstrated that the majority of foraminifera live in the $0-1 \mathrm{~cm}$ interval and that infaunal assemblages are unlikely to distort RSL reconstructions developed using training sets composed of surface sediment samples. Each sample was placed in a vial with rose Bengal and buffered ethanol to allow differentiation of live and dead specimens (Walton, 1952). Samples were processed by washing them over $500 \mu \mathrm{m}$ and $63 \mu \mathrm{m}$ sieves under running water to isolate and retain the foraminifera-bearing fraction of the sediment. This well-mixed sediment was suspended in water from which at least 100, randomlyselected, dead individuals were enumerated to ensure a statisticallysound representation of the assemblage (Fatela and Taborda, 2002). We combined all Ammobaculites species into one group due to the difficulty of species-level identification for individuals that are frequently broken.

We measured sample altitude (relative to the North American Vertical Datum of 1988; NAVD88) and the geographic location of each sample using a Leica GS15 global navigation satellite system. We tied the elevation of each sample to local tidal datums by including a tidal benchmark (872 6436 A 1977; Fig. 1) in our survey. This benchmark is a part of the network of elevation controls established for the Little Manatee River tide gauge. Its elevation with respect to local tidal datums is provided by NOAA and we used this information to convert from NAVD88 to tidal datums. This approach was repeated at the four sites in Charlotte Harbor where modern samples were collected through a survey that included NOAA Harbour Heights tide gauge and tidal benchmark 5791D 2008 (Fig. 1). Since each of the five salt marshes from which we collected modern samples have similar great diurnal tidal ranges $(0.60 \mathrm{~m}$ at Little Manatee River and $0.61 \mathrm{~m}$ in Charlotte Harbor), we combined all of the surface distributions into a single, regional-scale dataset, where species abundances were expressed as percentages. To objectively define the number and composition of foraminiferal assemblages in this modern training set we used Partitioning Around Medoids (PAM; Kaufman and Rousseeuw, 1990; Rousseeuw, 1987). This clustering technique seeks to minimize within group variance, while maximizing the dissimilarity among groups. Analysis was completed in the 'cluster' package for $R$ (Maechler et al., 2005). The total number of assemblages present was chosen by calculating the average silhouette width measured by PAM for 2-20 groups. The number of assemblages was chosen based on the group with the maximum, average silhouette width. Silhouette widths are values between -1 (poor fit) and +1 (good fit) that measure how well a sample was clustered.

We determined the length of the modern training set's environmental gradient using detrended correspondence analysis (DCA), executed in the 'Vegan' package for R (Oksanen et al., 2012). The purpose of this analysis was to decide whether linear or unimodal approaches were more appropriate for developing a transfer function to quantify the relationship between assemblages of foraminifera and tidal elevation from the modern training set (Birks, 1995; Juggins and Birks, 2012; Kemp and Telford, 2015). Based on our gradient length exceeding two standard deviations (2.69 standard deviations), we developed a transfer function using a unimodal method (weighted averaging partial least squares; WA-PLS) in the software package C2 (Juggins, 2011). WA-PLS was chosen from several possible unimodal methods because it is ecologically plausible and has a demonstrated history of generating reliable paleoenvironmental reconstructions from biological assemblages (e.g., Juggins and Birks, 2012), including PME reconstructions from salt-marsh microfossils (for a review see Barlow et al., 2013). No samples were screened from the dataset and we used the dead foraminiferal assemblage expressed as percentages. Transfer function performance was assessed using crossvalidation (10,000 bootstrapping cycles) and quantified through root mean squared error of prediction (RMSEP; expressed in meters) and the correlation between observed and predicted values $\left(r_{\text {boot }}^{2}\right)$. In choosing which component (1-5) of the WA-PLS model to use, we followed the guidelines presented by Barlow et al. (2013) that seek to balance model performance against the possibility of overfitting the data.

\subsection{Sediment coring}

We determined the stratigraphy beneath the Little Manatee River site by describing hand-driven cores along three transects (Fig. 3). We chose core LMR-9 for analysis because it included the thickest $(1.04 \mathrm{~m})$, continuous accumulation of salt-marsh peat with abundant and in situ Juncus roemerianus macrofossils. We collected LMR-9 using a hand-operated "Russian" half-barrel coring device to prevent compaction and/or contamination during extrusion. The recovered sediment was secured in rigid pipe sections with plastic wrap and refrigerated until laboratory analysis to minimize drying and/or oxidation. The orthometric and tidal elevation of each core top was established using the same instruments and methods as employed for surface sediment samples (Section 3.1).

\subsection{Developing a chronology for LMR-9}

The accumulation history of LMR- 9 was constrained by radiocarbon dating and recognition of pollution, ${ }^{137} \mathrm{Cs}$ and historic pollen markers of known age. In-situ Juncus roemerianus macrofossils (stems and rhizomes) and small pieces of wood were separated from the sediment matrix throughout the entirety of LMR- 9 by careful disarticulation of sediment

Table 1

Tidal datums.

\begin{tabular}{|c|c|c|c|c|c|c|c|}
\hline Site & NOAA ID & MHHW (m) & MHW (m) & MTL (m) & MSL (m) & MLW (m) & MLLW (m) \\
\hline Little Manatee River & 8725791 & 1.52 & 1.44 & 1.24 & 1.24 & 1.04 & 0.91 \\
\hline Harbour Heights & 8726436 & 1.36 & 1.31 & 1.07 & 1.07 & 0.84 & 0.76 \\
\hline
\end{tabular}

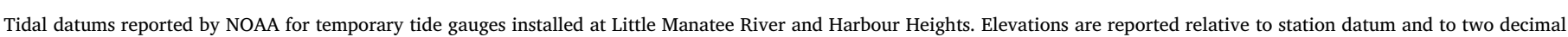
places. 
Table 2

Radiocarbon data for core LMR-9.

\begin{tabular}{|c|c|c|c|c|c|c|}
\hline Depth $(\mathrm{cm})$ & NOSAMS ID & Material & ${ }^{14} \mathrm{C}$ age & ${ }^{14} \mathrm{C}$ error & Calibrated age (cal yrs. BP; $2 \sigma$ range) & $\delta^{13} \mathrm{C}(\%, \mathrm{VPDB})$ \\
\hline 32 & OS-124600 & Wood & 155 & 15 & $4-281$ & -26.52 \\
\hline 42.5 & OS-117078 & Juncus roemerianus rhizome and stem & 315 & 15 & $307-451$ & -26.87 \\
\hline 45.5 & OS-120430 & Juncus roemerianus rhizome and stem & 350 & 15 & $318-480$ & -27.25 \\
\hline 53 & OS-122169 & Wood & 500 & 15 & $512-538$ & -26.54 \\
\hline 55 & OS-122170 & Wood & 320 & 15 & $308-454$ & -25.92 \\
\hline 59 & OS- 124620 & Wood & 525 & 15 & $518-547$ & -26.56 \\
\hline 65 & OS-122171 & Wood & 630 & 20 & $556-660$ & -25.92 \\
\hline 74 & OS-122172 & Wood & 1140 & 15 & $978-1170$ & -26.24 \\
\hline 80 & OS-122173 & Wood & 1240 & 20 & $1082-1263$ & -24.53 \\
\hline 87 & OS-124621 & Wood & 1810 & 15 & $1707-1814$ & -26.54 \\
\hline 95 & OS-124601 & Wood & 1940 & 20 & $1826-1932$ & -28.69 \\
\hline 100 & OS-117075 & Juncus roemerianus rhizome and stem & 2150 & 20 & $2060-2300$ & -27.91 \\
\hline 106.5 & OS-120368 & Juncus roemerianus rhizome and stem & 2140 & 15 & 2061-2294 & -28.02 \\
\hline 110 & OS-122175 & Wood & 2120 & 20 & $2007-2150$ & -27.54 \\
\hline 120 & OS-116955 & Juncus roemerianus rhizome and stem & 2100 & 20 & $2001-2129$ & -28.41 \\
\hline 120 & OS-120322 & Juncus roemerianus rhizome and stem & 2180 & 15 & 2126-2305 & -27.46 \\
\hline
\end{tabular}

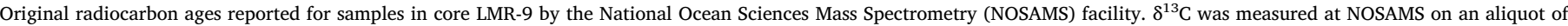
combusted samples and is reported with respect to the Vienna Pee Dee Belemnite (VPDB) standard.

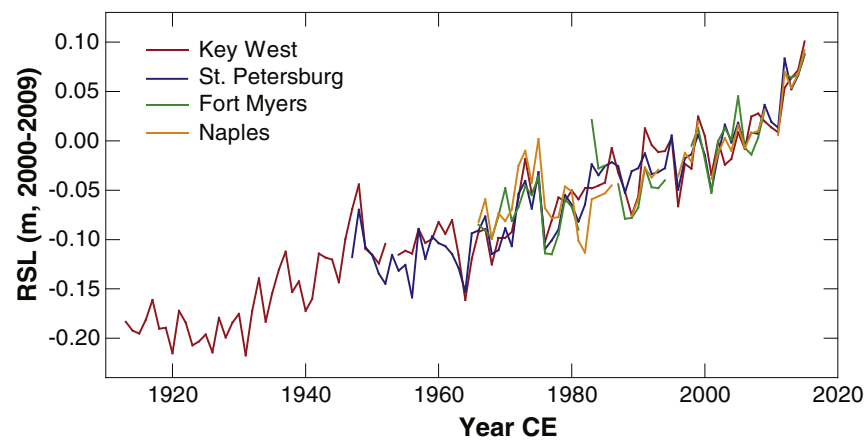

Fig. 2. Annual-average relative sea level measured by four long-running tide gauges on the Gulf of Mexico coast of Florida. Data were downloaded from the Permanent Service for Mean Sea Level and each series is expressed relative to the 2000-2009 CE average. The high degree of coherence among the records indicates that they individually and collectively represent regional-scale trends.

under light microscopy. Juncus roemerianus macrofossils are accurate indicators of paleo-marsh surfaces because of their close proximity (within a few $\mathrm{cm}$ ) to the surface and their short lifespan (approximately 3 years for rhizomes; Eleuterius, 1975, 1976; which are the preferred macrofossil for dating paleo marsh surfaces). In addition, we isolated small pieces of wood that we assumed were deposited on a paleomarsh surface. We purposefully chose small pieces of wood found in horizontal orientation in the core that we consider to be reliable material for accurately dating paleo marsh surfaces. Due to the growth below the surface, a Juncus roemerianus macrofossils and wood pieces found at the same depth may not be dating the same paleomarsh surface. We selected samples for further preparation by balancing macrofossil quality (preservation state and with a preference for Juncus roemerianus macrofossils rather than pieces of wood where both types of material were available) with approximately even spacing down core. At depth intervals where Juncus roemerianus macrofossils were absent or too badly degraded to reliably isolate a single sample of adequate quality to date, we relied on radiocarbon dating wood fragments. The chosen samples were cleaned under a binocular microscope to remove any younger in-growing rootlets and older sediment. Samples were sent to the National Ocean Science Accelerator Mass Spectrometer (NOSAMS) laboratory for dating. Each sample underwent acid-base-acid pretreatment and conversion to graphite at NOSAMS.

A plateau on the radiocarbon calibration curve hinders efforts to precisely radiocarbon date (pre-bomb spike) material younger than $\sim 300$ years. To decipher the recent accumulation history of LMR-9, we therefore identified environmental changes of known age using down- core changes in pollutant concentrations (arsenic and lead), the measured activity of ${ }^{137} \mathrm{Cs}$, and pollen (introduction of the non-native species Casuarina equisetifolia as an ornamental tree). Prior to elemental analysis by mass spectrometry, the upper $35 \mathrm{~cm}$ of LMR- 9 was cut into contiguous, $1-\mathrm{cm}$ thick sections, ground to a fine, homogenized powder and sent to SGS Mineral Services Canada laboratory for commercial analysis. ${ }^{137} \mathrm{Cs}$ activities were determined from the $661.7 \mathrm{KeV}$ gamma peak following the counting protocols described in Smoak et al. (2013) and Breithaupt et al. (2014). Pollen was isolated from 1-cm thick core samples using standard palynological preparation techniques (Traverse, 2007) and at least 300 pollen grains and spores were counted from each sample to determine relative abundance.

Interpreting downcore pollution profiles in western Florida did not utilize national production and consumption records because prevailing winds do not deliver emissions from the primary industrial centers located in the midwest, northeast and mid-Atlantic regions of the United States. The Florida peninsula experiences a prevailing trade wind regime that brings air onshore from the Atlantic Ocean, compared to much of the continental U.S., where westerlies are the prevailing wind pattern. Therefore, the trends and timings of pollution used elsewhere on the U.S. Atlantic coast to assign ages to salt-marsh sediment (e.g., Kemp et al., 2012) are not applicable to our study site. Our interpretation utilizes local- to regional-scale records of leaded gasoline consumption (onset in 1930 CE \pm 5 years; peak in 1974 CE \pm 5 years; e.g., Nriagu, 1990) and the use of arsenic-bearing herbicides that were widely sprayed on citrus fruit groves on industrial scales and more locally on lawns and golf courses (onset of $1955 \mathrm{CE} \pm 5$ years; Wojeck et al., 1982; Whitmore et al., 2008). From downcore pollen counts, we identified the known arrival (1905 CE \pm 10 years) of the non-native tree Casuarina equisetifolia (Alexander and Crook, 1974) that was brought to Florida as an ornamental. Each age marker was assigned an age and a depth uncertainty. The age uncertainty accounted for both identifying a specific date in historical records and the lag (where necessary) between emission and deposition. The depth uncertainty recognizes that horizons could be associated with multiple, adjacent depths in the core. We assumed that pollutants were deposited primarily from the atmosphere on to the saltmarsh surface within a few years of emission (e.g., Graney et al., 1995; Lima et al., 2005).

All discrete age-depth estimates from radiocarbon dating and marker horizons were compiled in Bchron (Haslett and Parnell, 2008; Parnell et al., 2011; Parnell and Gehrels, 2015) to produce an age-depth model that describes the accumulation history of LMR-9. An advantage of this approach is that Bchron (and similar age-depth models) are able to accommodate discrete age estimates from different methods and the unusual probability distributions that arise from calibration of radiocarbon ages (see for example Wright et al., 2017). Chronohorizons established 

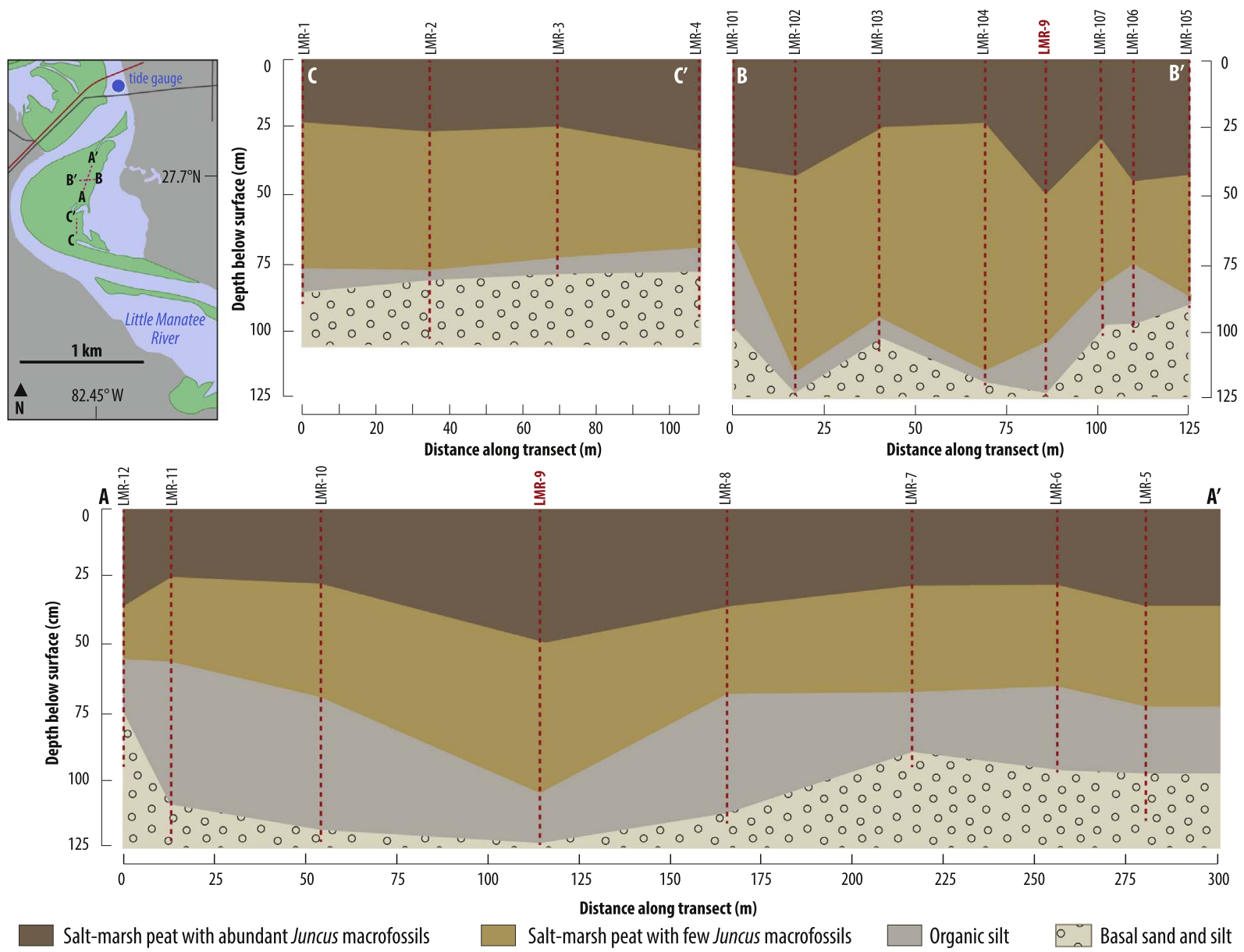

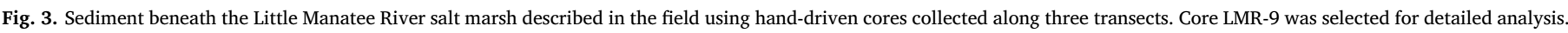

from pollution, ${ }^{137} \mathrm{Cs}$ and pollen markers were treated as having normal probability distributions, and no weighting was applied to any of the age estimates. The resulting suite of equi-probable chronologies is summarized by Bchron to estimate sample ages with a $95 \%$ credible interval. Throughout the text, Bchron results are reported as a mean with $95 \%$ credible interval.

\subsection{Reconstructing relative sea level}

We initially counted foraminifera preserved in $1-\mathrm{cm}$ thick slices of LMR-9 at 3-cm resolution. Additional samples were counted from stratigraphic contacts, where assemblages changed and at dated depths. Sample preparation and counting followed the approach used for surface samples (except for staining with rose Bengal). The WA-PLS transfer function was applied to assemblages of foraminifera within LMR-9 to estimate PME with a sample-specific, $\sim 1 \sigma$ uncertainty (e.g., Juggins and Birks, 2012; Kemp and Telford, 2015). To assess the ecological plausibility of the PME estimations, we measured the dissimilarity between foraminiferal assemblages in core material and their closest modern analogue using the Bray-Curtis distance metric (Jackson and Williams, 2004). If the minimum dissimilarity exceeded the 20th percentile of dissimilarity measured among all possible pairings of samples in the modern trainings set, then we excluded the core sample from the resulting RSL reconstruction (e.g., Simpson, 2012).

Relative sea level was reconstructed using the equation:

$R S L_{i}=A_{i}-P M E_{i}$

where $A_{i}$ and $P M E_{i}$ are the altitude and PME of sample $i$ respectively and both quantities are expressed relative to mean high water (MHW). $A_{i}$ was established by subtracting the depth of each sample in the core from the measured core-top altitude and is therefore a fixed and known value.
$P M E_{i}$ was estimated with uncertainty using the WA-PLS transfer function. For a modern (surface) sample, the terms $A_{i}$ and $P M E_{i}$ are equal, thus RSL is zero. Each 1-cm thick sample in LMR-9 with reconstructed PME was assigned an age estimate from the age-depth model with an associated uncertainty ( $95 \%$ credible interval).

\subsection{Quantification of relative sea-level trends}

Annual tide-gauge measurements from four locations on Florida's Gulf Coast (Fig. 2) show similar RSL trends and variations, justifying the creation of a combined instrumental record (with the caveat that Key West was the only one of these four tide gauges to be in operation for 1913-1947 CE). Decadal averages calculated across the four tide gauges and expressed relative to $2013 \mathrm{CE}$ (year of core collection) provide a regional-scale, instrumental record of RSL change. Vertical uncertainty was estimated by calculating the standard deviation across the tide gauges and averaging them by decade for 1913-2014 CE. A vertical uncertainty $(1 \sigma)$ of $\pm 0.022 \mathrm{~m}$ was applied to each decadally-averaged data point along with an age uncertainty of \pm 5 years (1913-1919 CE was given an age uncertainty of \pm 4 years and 2010-2014 CE was assigned an age uncertainty of \pm 2 years) that we conservatively treated as a $2 \sigma$ range. The regional tide-gauge record was combined with the RSL reconstruction to produce a single RSL dataset for the Gulf Coast of Florida. A study by Kemp et al. (in press) compared a proxy-only reconstruction to a combined proxy/tide-gauge reconstruction and demonstrated that the two approaches yielded (within uncertainty) the same RSL history. However, they noted that inclusion of the tide-gauge data had the advantage of reducing uncertainty. Some earlier studies generated composite RSL records by merging tide-gauge data with pre-20th century proxy reconstructions from salt marshes (e.g., Donnelly et al., 2004; Gehrels et al., 2002), while others validated proxy reconstructions through 
comparison with nearby tide-gauge measurements, but chose not to combine the two, independent data sources (e.g., Kemp et al., 2009a).

Quantitative RSL trends with uncertainties were estimated by applying the Error-In-Variables Integrated Gaussian Process (EIV-GP) model of Cahill et al. (2015) to the combined RSL dataset. This method captures the continuous and dynamic evolution of RSL change with full consideration of sample-specific vertical and temporal uncertainty and the uneven distribution of data points through time. This model also accommodates removal of linear trends (e.g. from GIA) by accounting for the co-variance in uncertainties that is introduced as a result of this detrending step. The linear trend is specified by the user and treated by the model as a fixed and known value without uncertainty. Uncertainties reported in the text from the EIV-IGP model are a mean with $95 \%$ credible interval. We also used errors-in-variables change-point analysis to estimate when (with uncertainty) modern rates of sea-level rise began following the approach described in Kemp et al. (2013).

\section{Results}

\subsection{Modern distribution of salt-marsh foraminifera}

We identified 12 taxa of agglutinated foraminifera in the dead assemblage of 66 surface sediment samples collected from five salt marshes in the Tampa Bay and Charlotte Harbor estuaries (Fig. 4 and tabulated in Supplementary data 1). Application of PAM to this dataset identified four distinct assemblages of foraminifera based on the highest average silhouette width (0.35) calculated for 2-20 groups. Assemblage one is composed of two samples from the Sand Point transect in Charlotte Harbor, which were the lowest sampled elevations $(-0.45 \mathrm{~m}$ to $-0.36 \mathrm{~m} \mathrm{MHW}$ ) in our modern dataset. The elevation range of this assemblage does not overlap with any of the other three groups. These samples were dominated by Ammobaculites spp. (average $88 \%$ individuals) and occurred in a tidal-flat environment. Assemblage two included samples from three sites (Drift Island, Long Island and Little Manatee River) and spanned elevations from -0.25 to $0.06 \mathrm{~m}$ MHW, although 15 of the 21 samples in this group occurred below MHW. These samples exhibit an approximately equal abundance of Ammobaculites spp., Miliammina fusca, Arenoparrella mexicana and Ammoastusta inepta. Assemblage three included samples from all five sites that were dominated by $A$. inepta, A. mexicana and Haplophragmoides wilberti (together, these three species accounted for $74 \%$ individuals on average) between elevations of -0.17 to $0.16 \mathrm{~m}$ MHW. Assemblage four was comprised of 16 samples in which $A$. mexicana was the most commonly identified taxon (average $48 \%$ of individuals). This cluster encompassed an elevational range of $-0.13 \mathrm{~m}$ to $0.13 \mathrm{~m}$ MHW and was present at Drift Island, Long Island and Sand Point in the Peace River estuary of Charlotte Harbor.

\subsection{Stratigraphy at Little Manatee River}

We described the stratigraphy beneath the Little Manatee River study site using 19 cores (0.75-1.25 m long) collected along three transects (A$\mathrm{A}^{\prime}$, B-B', and C-C'; Fig. 3). The stratigraphy is consistent among all three transects and comprised of salt-marsh peat with $J$. roemerianus macrofossils overlying organic silt (0.05-0.50 m thick) and a basal unit of sand and silt that we interpret to be an incompressible substrate. The greater thickness of these units at A-A' and B-B' compared to C-C' likely reflects the initiation of marsh development at the northern portion of the site with later development in the southern section. These sedimentary successions indicate that salt-marshes initially colonized tidal-flat or shallow sub-tidal shoal environments (e.g., Redfield, 1965).

\subsection{Foraminifera in LMR-9}

The core top elevation of LMR-9 was $-0.12 \mathrm{~m}$ MHW. LMR-9 was comprised of $1.04 \mathrm{~m}$ of high salt-marsh peat with abundant and in-situ $J$. roemerianus macrofossils (Fig. 3), below which was $\sim 0.20 \mathrm{~m}$ of organic silt and sand that became less organic with depth and included sparse $J$. roemerianus macrofossils. At the base of recovery was a sand unit that we assume to be an incompressible substrate. Foraminifera were present in LMR-9 at all sampled depths in the organic silt and peat units (Fig. 5; Supplementary data 1). Fifteen samples yielded 50-99 foraminifera and 59 samples provided counts $\geq 100$ individuals. From $124 \mathrm{~cm}$ to $108 \mathrm{~cm}$, foraminiferal assemblages were dominated by Ammobaculites spp. and $M$. fusca (average $67 \%$ of individuals when combined). A transition to an assemblage composed primarily of $A$. inepta and $A$. mexicana occurred at $108 \mathrm{~cm}$ to $100 \mathrm{~cm}$. This change occurs in samples that mark the stratigraphic switch from organic silt to salt-marsh peat with more abundant $J$. roemerianus macrofossils. A. inepta and A. mexicana remain abundant to $85 \mathrm{~cm}$ (average 68\% when combined), above which $H$. wilberti is also present to form an assemblage in which these three species constitute an average of $89 \%$ of individuals when combined. Within this zone the interval at 59-48 cm had increased abundances of Ammobaculites spp. and M. fusca (average $20 \%$ of individuals when combined).

\subsection{Chronology for LMR-9}

Sixteen radiocarbon dates (Table 2) demonstrate that LMR-9 spans the period since $\sim 300$ BCE. The initial increase of lead concentrations above backgrounds levels $(<5 \mathrm{mg} / \mathrm{kg})$ at $11-16 \mathrm{~cm}$ in LMR-9 was interpreted to be the result of the introduction of leaded gasoline and increased private ownership of motor vehicles in western Florida during the 1930s (e.g., Escobar et al., 2013; Facchetti, 1989). We therefore assigned this feature an age of $1930 \mathrm{CE} \pm 5$ years (Fig. 6A). Peak lead emissions were curtailed by the Clean Air Act, which saw leaded gasoline consumption decline sharply. For example, in $1993 \mathrm{CE}$ lead emissions from gasoline use in the U.S. fell to 1\% of those in 1970 CE (Bollhöfer and Rosman, 2001). Since gasoline was the major source of lead pollution in our study area in the absence of heavy industry and prevailing winds that delivered pollutants from other regions, we assigned the peak concentration of lead at $\sim 6 \mathrm{~cm}$ an age of $1974 \mathrm{CE} \pm 5$ years (Fig. 6A). The onset of increased arsenic concentration above background levels of $<$ $10 \mathrm{mg} / \mathrm{kg}$ occurred at 7-11 cm in the core (Fig. 6A). We interpret this trend to reflect use of arsenic-bearing compounds as herbicides for citrus fruit groves, lawns and golf courses that began in Florida during the 1950s (Wojeck et al., 1982; Whitmore et al., 2008) and consequently assigned it an age of $1955 \mathrm{CE} \pm 5$ years. Maximum downcore ${ }^{137} \mathrm{Cs}$ activity in LMR-9 occurred at $\sim 8 \mathrm{~cm}$ and was assigned an age of $1963 \mathrm{CE} \pm 1$ year because it was produced by peak above-ground testing of nuclear weapons. The first reliable occurrence of Casuarina pollen in LMR-9 was at 19-25 cm and corresponds to the introduction of Casuarina equisetifolia as an ornamental species at the turn of the 20th century (Alexander and Crook, 1974; Morton, 1980; Fig. 6A). A sample analyzed at $26 \mathrm{~cm}$ yielded a single grain of Casuarina pollen that we did not treat as the first occurrence because Casuarina pollen is difficult to distinguish from Myrica and multiple counts are required to be confident in the interpretation. All radiocarbon dates and marker horizons were used to develop an age-depth model (Fig. 6B) for LMR-9 using Bchron (Haslett and Parnell, 2008). The model generated an age-estimate (with $95 \%$ credible interval) for each $1-\mathrm{cm}$ thick interval throughout the core with an average uncertainty of \pm 68 years. The age-depth model produced by Bchron demonstrates that the organic sand and silt unit at the base of the core was deposited rapidly from $350 \mathrm{BCE}$ to $100 \mathrm{BCE}$ (Fig. 6C). This section of the core is characterized by high relative abundances of Ammobaculites spp. At 100 BCE, the deposition of saltmarsh peat was initiated, which corresponds to a decreased rate of sediment accumulation and a foraminiferal assemblage composed of $A$. mexicana, A. inepta, and $H$. wilberti. The sedimentation rate increased again at $\sim 1500 \mathrm{CE}$, associated with a return to Ammobaculites spp. comprising up to $\sim 20 \%$ of the assemblage, although no change in the type of sediment deposited is observed. A final increase in the rate of sedimentation occurred at $\sim 1900 \mathrm{CE}$ and continues to present.

\subsection{Reconstructing paleo marsh elevation}

We constructed a WA-PLS transfer function using the entire modern 


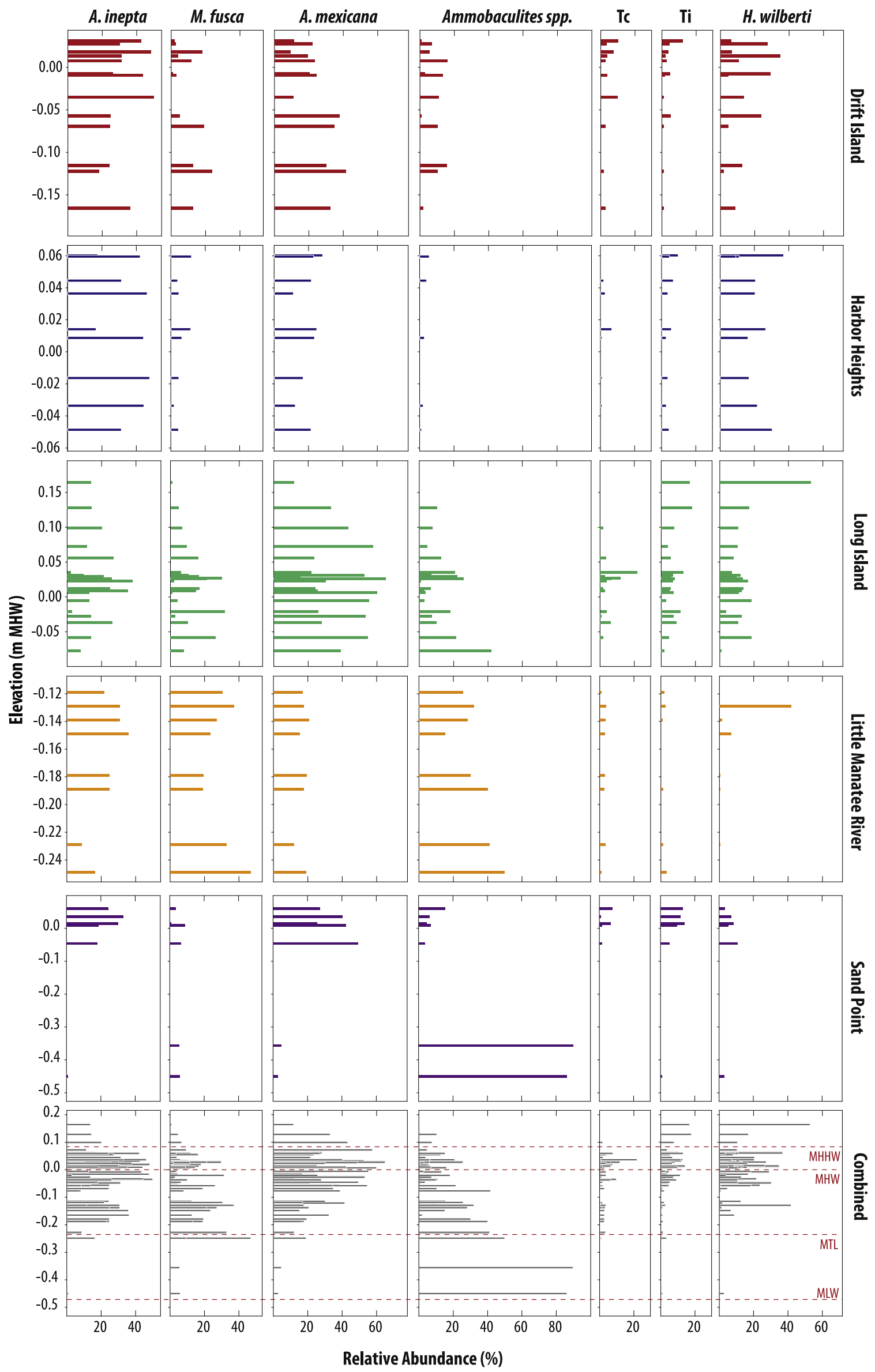




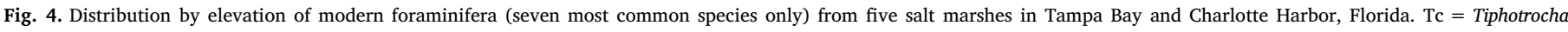

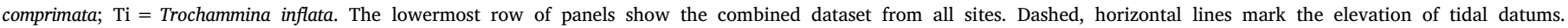
MHHW = mean higher high water; MHW = mean high water; MTL = mean tide level; MLW = mean low water.

training set and followed the recommendation of Barlow et al. (2013) by selecting component two because it improved model performance measured by RMSEP by $4.6 \%$ in comparison to component one. The transfer function had an $\mathrm{r}_{\text {boot }}^{2}$ of 0.67 and a RMSEP of $0.07 \mathrm{~m}$ (Table 3; Fig. 7). Application of the WA-PLS transfer function to foraminiferal assemblages in LMR-9 (Fig. 5) provided PME estimates ranging from $-0.34 \mathrm{~m}$ to $0.04 \mathrm{~m}$ MHW with sample-specific uncertainties $(\sim 1 \sigma)$ of $\pm 0.06-0.08$ $\mathrm{m}$, equivalent to $10-13 \%$ of the great diurnal tidal range at Little Manatee River. Estimates of PME increased from $-0.34 \mathrm{~m}$ MHW to $-0.10 \mathrm{~m}$ MHW at a depth of $108 \mathrm{~cm}$. This trend is driven by the decreasing abundance of Ammobaculites spp. and its replacement by the high saltmarsh species of $A$. mexicana, $A$. inepta and $H$. wilberti. PME values from this depth to the top of LMR-9 generally remained within $\pm 0.05 \mathrm{~m}$ of MHW, except for an interval at 58-48 cm, where estimated PME decreased to $-0.10 \mathrm{~m}$ MHW in response to increased abundances of $M$. fusca and Ammobaculites spp.

To identify samples lacking a modern analogue, dissimilarity between assemblages of foraminifera preserved in core samples and their modern counterparts was measured using the Bray-Curtis metric. Five samples (at 19-20 cm; 31-32 cm; 73-74 cm; 76-77 cm; 82-83 cm) had a measured minimum dissimilarity greater than the 20th percentile of dissimilarity measured among all pairings of modern samples and were excluded from further analysis. These core samples included higher abundances of $H$. wilberti ( $>76 \%$ ) than any sample in the modern training set, where the highest recorded abundance of $H$. wilberti was $52 \%$. The closest modern analogues for the remaining foraminiferal samples were drawn from all five sites within our modern training set, which demonstrates the value of a regional-scale dataset for interpreting downcore assemblages of saltmarsh foraminifera in southwestern Florida.

\subsection{Relative sea-level trends}

RSL was reconstructed by subtracting estimated PME from the measured altitude of each sample in LMR-9 (equation 1). The age of each sample with uncertainty (all uncertainties reported hereafter are the $95 \%$ credible interval) was estimated from the age-depth model (Fig. 6). RSL at Little Manatee River fell from approximately $-0.86 \mathrm{~m}$ at $500 \mathrm{BCE}$ to $-1.00 \mathrm{~m}$ at $350 \mathrm{BCE}$, after which it rose continuously until present (Fig. 8B). The regional tide-gauge data lies within the uncertainties of the proxy-based reconstruction demonstrating that these two data sources can reasonably be combined to provide a RSL history for our study area.

Application of the EIV-GP model (Fig. 8C) to the combined dataset shows that RSL fell at a maximum rate of $-0.67 \mathrm{~mm} / \mathrm{yr}$. $(-1.51$ to $0.16 \mathrm{~mm} / \mathrm{yr}$ ) at $\sim 350 \mathrm{BCE}$, before stabilizing at $\sim 100 \mathrm{BCE}$ and rising at $\sim 0.2 \mathrm{~mm} / \mathrm{yr}$ ( -0.03 to $0.48 \mathrm{~mm} / \mathrm{yr})$ until $\sim 1000 \mathrm{CE}$. RSL continued rising, but at an increased rate of $0.5 \mathrm{~mm} / \mathrm{yr}(0.27-0.71 \mathrm{~mm} / \mathrm{yr})$ to $\sim 1600 \mathrm{CE}$, and then accelerated until a rate of $2.27 \mathrm{~mm} / \mathrm{yr}$ $(1.73-2.81 \mathrm{~mm} / \mathrm{yr})$ was reached in $2014 \mathrm{CE}$. Change-point analysis performed on the combined proxy and instrumental dataset revealed two inflexion points in RSL change. The first change point is associated with a slight acceleration in RSL rise that occurred at 1000-1430 CE. The second change point is the onset of modern rates of RSL rise at 1830-1940 CE.

\section{Discussion}

\subsection{Distribution of modern salt-marsh foraminifera}

The observed distribution of foraminifera on and around salt marshes in Tampa Bay and Charlotte Harbor is broadly consistent with modern distributions reported from salt marshes on the Gulf of Mexico coast in Texas (Phleger, 1965b), Louisiana (Scott et al., 1991), Mississippi
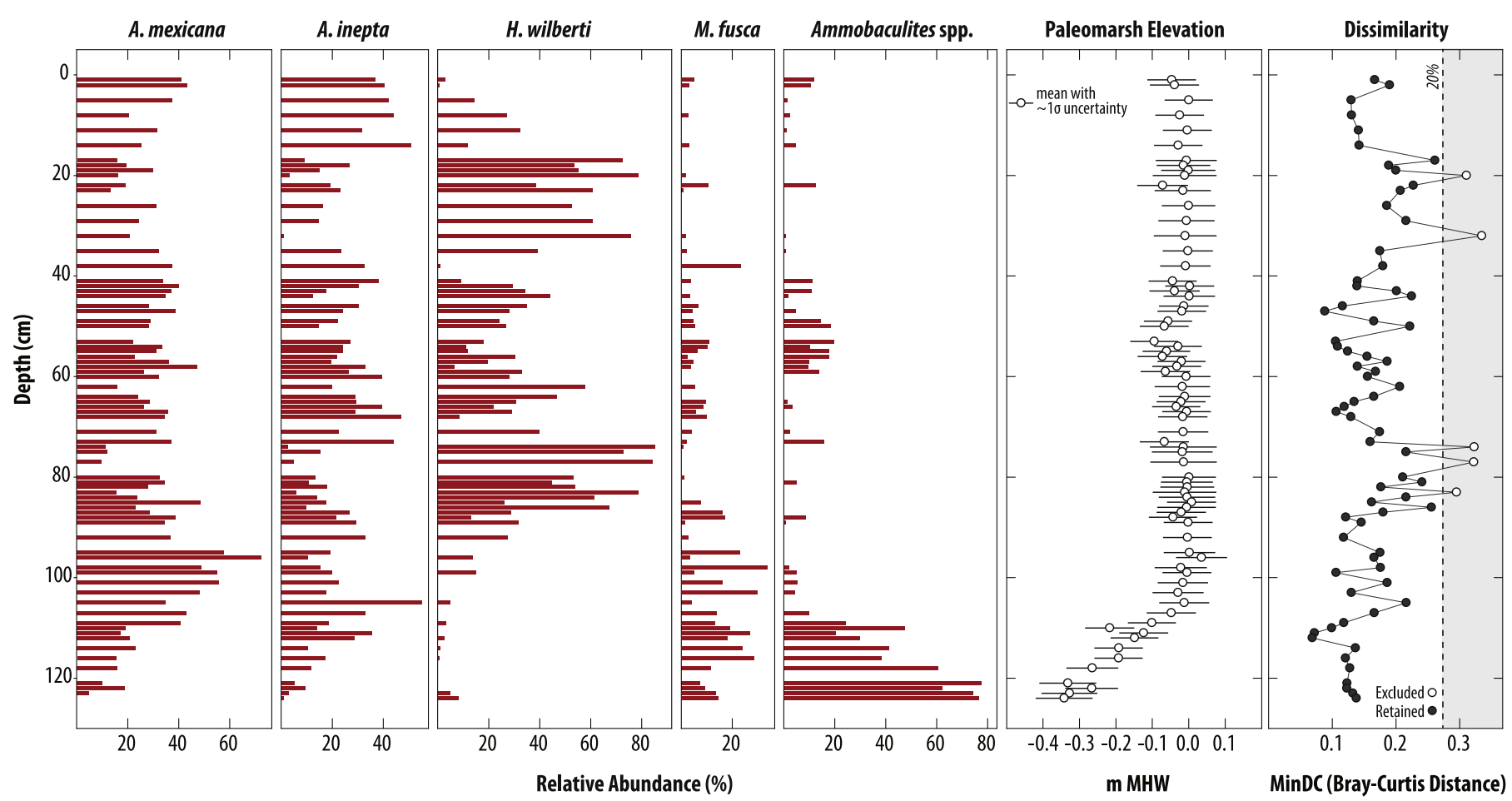

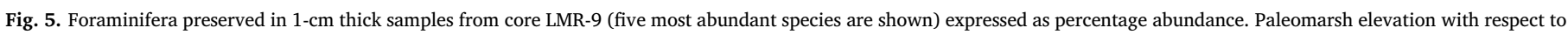

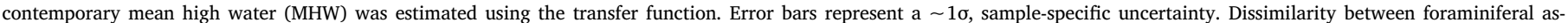

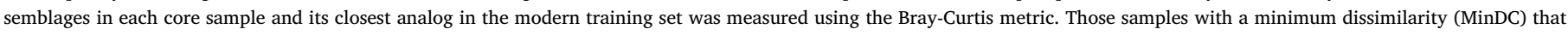
exceeded the 20th percentile of dissimilarities measured among all possible pairings of modern samples were excluded from the resulting relative sea level reconstruction. 

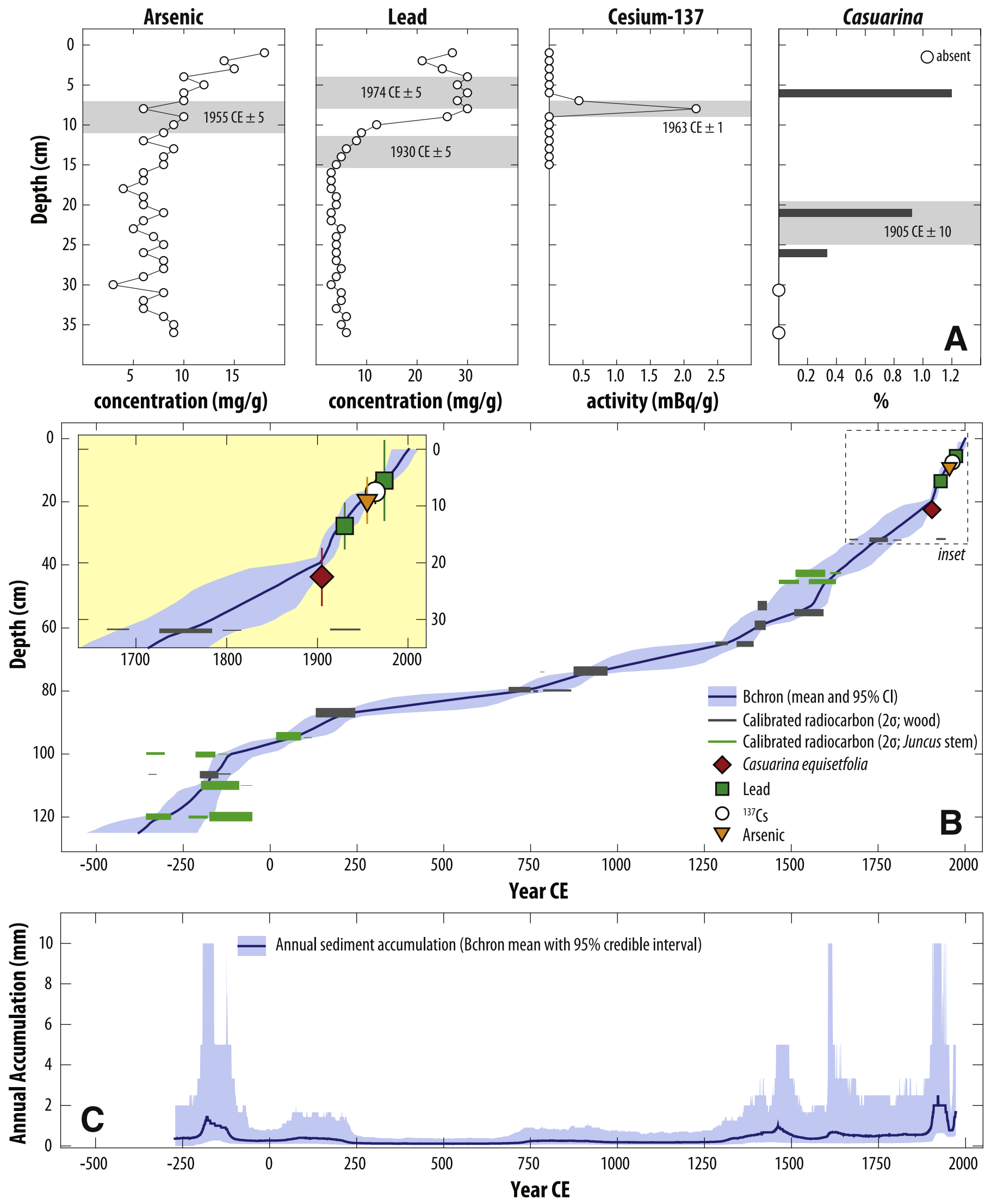

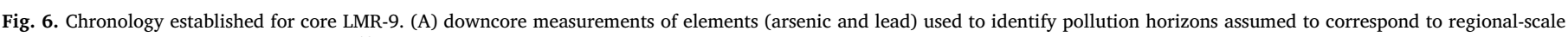

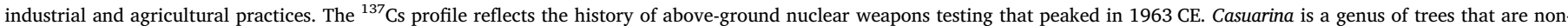

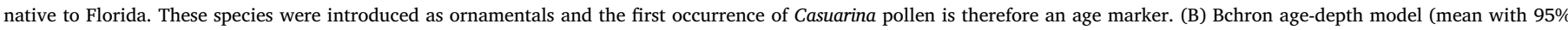

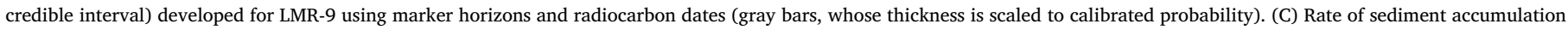
estimated for LMR-9 (mean with 95\% credible interval) using the Bchron age-depth model. 
Table 3

Transfer function statistics.

\begin{tabular}{lllll}
\hline Component & $\mathrm{r}^{2}$ & RMSE $(\mathrm{m})$ & Boot $\mathrm{r}^{2}$ & RMSEP $(\mathrm{m})$ \\
\hline 1 & 0.66 & 0.063 & 0.62 & 0.069 \\
2 & 0.74 & 0.056 & 0.67 & 0.066 \\
3 & 0.77 & 0.053 & 0.68 & 0.067 \\
4 & 0.78 & 0.051 & 0.68 & 0.070 \\
5 & 0.78 & 0.051 & 0.68 & 0.076 \\
\hline
\end{tabular}

Transfer function statistics reported for five components from our Weighted Averaging Partial Least Squares (WA-PLS) model.

(Lankford, 1959; Phleger, 1970) and Florida (Phleger, 1965a) as well as locations on the U.S. southeastern Atlantic coast in Florida (Kemp et al., 2014), Georgia (Goldstein and Frey, 1986; Goldstein and Watkins, 1998), South Carolina (Collins et al., 1995) and North Carolina (Kemp et al., 2009b). The tidal flat from MLW to MTL is represented by two samples that are dominated by Ammobaculites spp. The abundance of $M$. fusca peaks at approximately MTL, above which the occurrence of this species is negatively correlated with elevation. In contrast, the vegetated saltmarsh platform occurring around MHW supports a foraminiferal population composed of increasing abundances of $A$. mexicana and A. inepta, which display a near-normal distribution with elevation centered approximately on MHW. Samples above MHW yielded increasing abundances of Trochammina inflata and $H$. wilberti.

The vertical distribution of the samples in our modern training set reflects the geomorphology of salt marshes in the Tampa Bay and Charlotte Harbor estuaries. In this region, salt marshes that formed on remnant karstic features were infilled by siliciclastic material (e.g., Hine et al., 2009). This results in expansive salt-marsh platforms with minimal topographic relief outside of a step change in elevation between the intertidal platform and surrounding shallow sub-tidal settings. Furthermore, the platform marshes do not support supra-tidal communities and salt marshes on the margins of the estuaries are frequently subject to anthropogenic encroachment. Consequently, sampling elevation at regular intervals is unfeasible. Since the geological control on salt-marsh morphology in the study region is likely to have persisted through the past $\sim 2400$ years represented by core LMR-9 (e.g., Hine et al., 1988), we

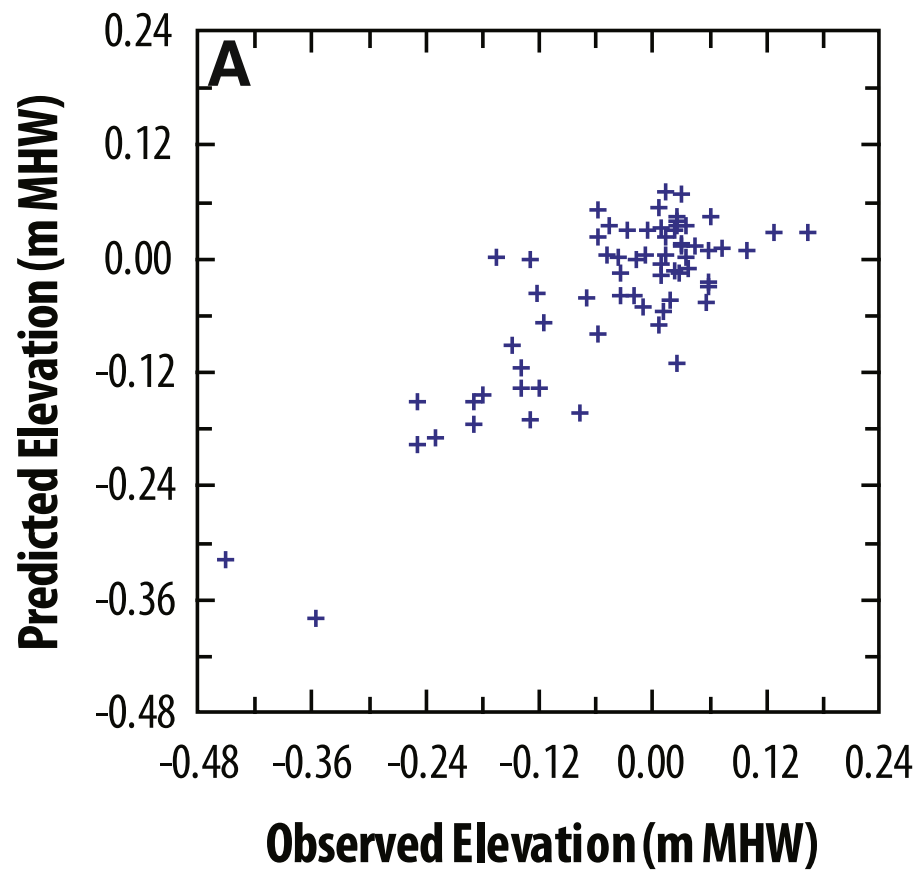

are confident that our modern training set constitutes an appropriate dataset for interpreting assemblages of foraminifera preserved in core material. While we did not sample open water and sub-tidal locations in Tampa Bay and Charlotte Harbor, previous research (e.g., Bandy, 1954; Bandy, 1956; Poag, 2015; Walton, 1964) demonstrates that the foraminiferal assemblages in these settings are significantly different to those that we observed on the sampled salt marshes. Although there is considerable overlap in the elevational ranges of groups two, three and four identified using PAM (Fig. 4) this does not diminish the utility of salt-marsh foraminifera as sea-level indicators. Regional-scale studies of the modern distribution of foraminifera frequently report that high saltmarsh environments are characterized by more than one assemblage, particularly where the training set is sufficiently large to include a variety of sites (e.g. Wright et al., 2011; Kemp et al., 2009b; Horton and Edwards, 2006). Since the upper and lower elevations of these distinct groups are strongly controlled by tidal inundation, each group meets the accepted criteria of being a sea-level proxy. This pattern is similar, for example, to the vertical distribution of salt-marsh plants. In the northeastern United States, high salt-marsh environments are most commonly vegetated by Spartina patens and Distichlis spicata. Although the two plants exist across the same range of elevations, each is a valid sea-level proxy in its own right because its distribution is controlled by tidal elevation. We contend that our modern training set provides a reasonable estimate of the lower limit of the assemblage dominated by Ammobaculites spp., when viewed in the context of site geomorphology and the documented distribution of assemblages dominated by calcareous taxa in nearby shallow sub-tidal environments.

\subsection{Estimation and removal of the glacio-isostatic adjustment contribution}

Millennial-scale, Common Era RSL trends on the North American Atlantic and Gulf Coasts are primarily driven by GIA (e.g., Peltier, 2004), which includes a land-subsidence component from the collapse of the Laurentide ice sheet's proglacial forebulge and a component from reshaping of the geoid in response to mass redistribution in the mantle (e.g., Farrell and Clark, 1976). Existing RSL reconstructions (e.g., Engelhart et al., 2009), tide-gauge data (e.g., Davis and Mitrovica, 1996), GPS measurements (e.g., Karegar et al., 2016) and Earth-ice models (e.g., Roy and Peltier, 2015) demonstrate that the contribution from GIA varies

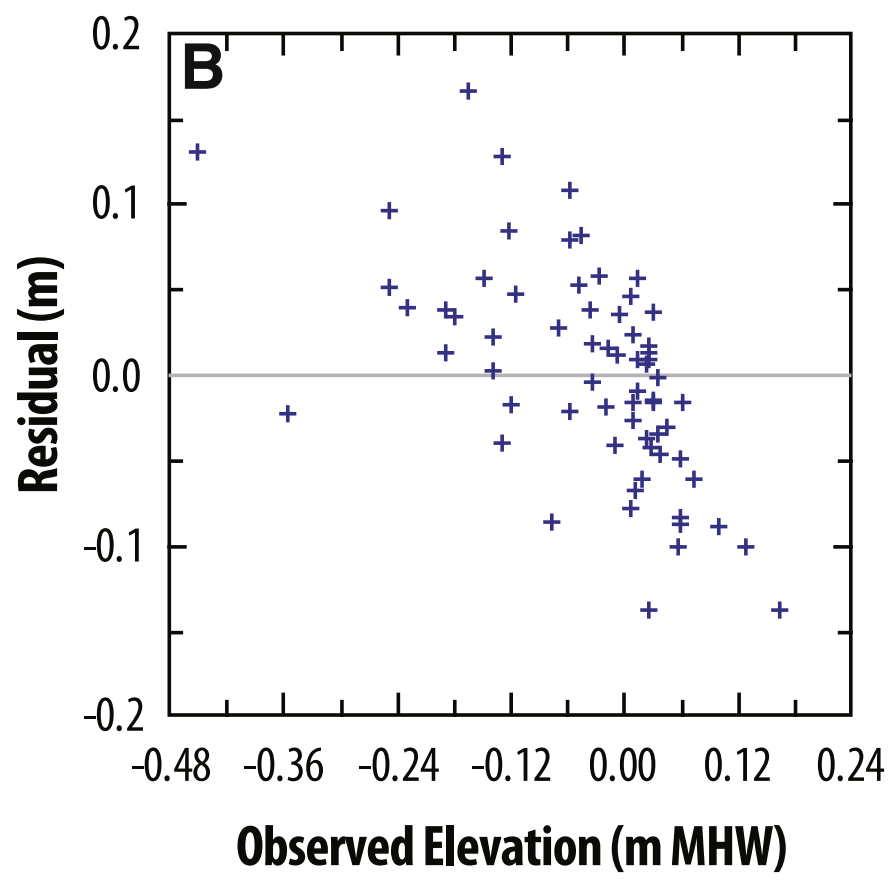

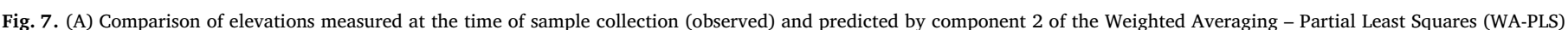

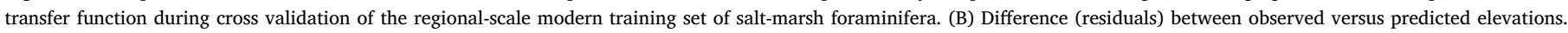
$\mathrm{MHW}=$ mean high water. 

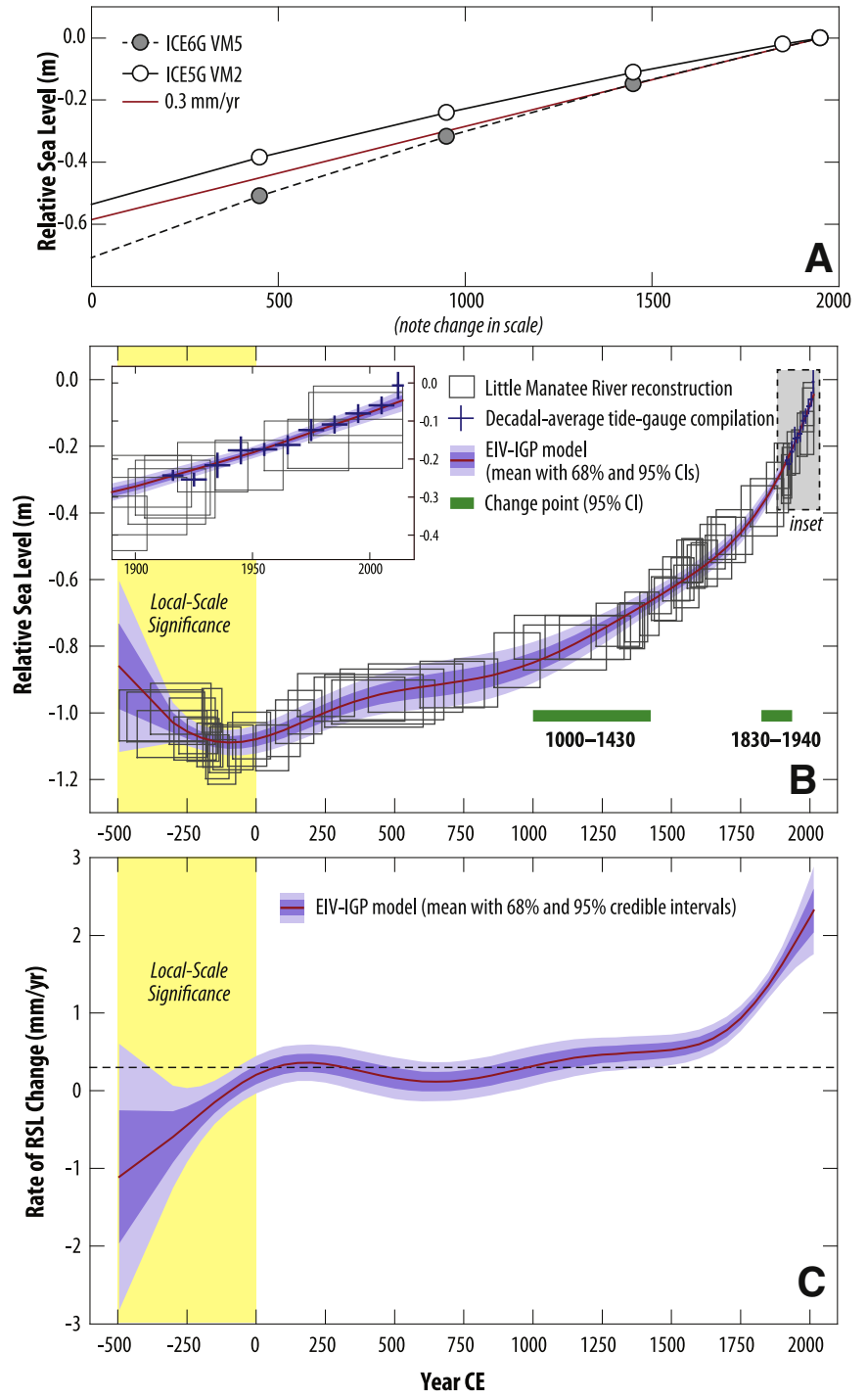

Fig. 8. (A) Relative sea-level prediction for Little Manatee River from two widely used Earth-ice models (Peltier, 2004; Peltier et al., 2014). For reference a linear rate of change $(0.3 \mathrm{~mm} / \mathrm{yr})$ is shown in red. (B) Relative sea-level reconstruction from Little Manatee River, Florida developed using foraminifera preserved in a core of dated salt-marsh sediment. Proxy reconstructions are represented by boxes whose width spans the age error of each sample from the Bchron age-depth model and whose height encompasses the vertical uncertainty from the transfer function. These proxy reconstructions were combined with decadal average tide gauge measurements (blue crosses) generated by merging annual average records from Key West, Naples, Fort Meyers and St. Petersburg for the period from 1913 to $2014 \mathrm{CE}$. The shaded and labeled interval prior to $\sim 0 \mathrm{CE}$ represents the time period where we contend that local-scale sedimentation processes were the dominant cause of reconstructed RSL trends. Application of the Error-in-Variables Integrated Gaussian Process (EIV-IGP) to the combined record described the continuous evolution of relative sea level through time (mean with shaded $68 \%$ and $95 \%$ credible intervals). Vertical shading denotes $95 \%$ credible interval for the timing of statisticallysignificant changes in the rate of RSL rise identified by change point analysis. (C) Rate of relative sea-level change (positive values denote rise) through time estimated by the EIVIGP model. The shaded and labeled interval prior to $\sim 0 \mathrm{CE}$ represents the time period where we contend that local-scale sedimentation processes were the dominant cause of reconstructed RSL trends. (For interpretation of the references to color in this figure legend, the reader is referred to the web version of this article.)

systematically with distance from the former center of the Laurentide ice sheet. To isolate climate-driven sea-level trends and to enable meaningful comparison of reconstructions from different regions, it is therefore necessary to remove the contribution of GIA (and any other sources of vertical land motion) from RSL records. Based on a linear fit to the new Little Manatee River RSL reconstruction (0-1800 CE), we estimated the background rate of RSL change in the study region to be $0.3 \mathrm{~mm} / \mathrm{yr}$. This rate is primarily driven by GIA, but may also include a small ( $<0.05 \mathrm{~mm} / \mathrm{yr}$ ) isostatic contribution (uplift; RSL fall) from karstification of the underlying carbonate platform because dissolution removes mass and consequently generates an isostatic response (Adams et al., 2010). This rate agrees with predictions from widely-used Earth-ice models (Fig. 8A), which estimated the rate of Common Era GIA at Little Manatee River to be $0.28 \mathrm{~mm} / \mathrm{yr}$ (ICE5G VM2; Peltier, 2004) to $0.37 \mathrm{~mm} / \mathrm{yr}$ (ICE6G VM5; Peltier et al., 2014). Using radiocarbon-dated mangrove peats in southwestern Florida (Fig. 1), Scholl and Stuiver (1967) and Scholl et al. (1969) estimated that the (pre-anthropogenic) rate of RSL change in the past $\sim 2000$ years was $0.30-0.35 \mathrm{~mm} / \mathrm{yr}$.

We removed $0.3 \mathrm{~mm} / \mathrm{yr}$ (without uncertainty) from the Little Manatee River reconstruction using the EIV-IGP model to account for the covariance of age and vertical uncertainties introduced by this adjustment (Cahill et al., 2015; Fig. 8). Over the Common Era in western Florida it is reasonable to treat the contribution from GIA (and other processes causing vertical land motion) as linear because the adjustment time of the solid Earth to deglaciation is slow (Farrell and Clark, 1976; Peltier, 1986). The resulting, detrended sea-level record reveals positive and negative departures from the background rate of rise over our 2400year record (Fig. 9). Sea level fell at a maximum rate of $-0.91 \mathrm{~mm} / \mathrm{yr}$. $(-1.71$ to $-0.12 \mathrm{~mm} / \mathrm{yr})$ at $\sim 300$ BCE before stabilizing at $\sim 100 \mathrm{BCE}$. After this time, the rate of sea-level change did not deviate significantly from zero until $\sim 1500 \mathrm{CE}$ when rates of sea-level rise began to accelerate, reaching $1.33 \mathrm{~mm} / \mathrm{yr}(1.11-1.56 \mathrm{~mm} / \mathrm{yr})$ in $1900 \mathrm{CE}$ and $2.02 \mathrm{~mm} / \mathrm{yr}(1.49-2.56 \mathrm{~mm} / \mathrm{yr})$ in $2014 \mathrm{CE}$. This is the fastest, centuryscale sea-level rise over the $\sim 2400$-year period covered by this record. Change-point analysis of the detrended data identified that a significant change in the rate of sea-level rise occurred at 1815-1957 CE (95\% credible interval; compared to 1834-1922 CE in northeastern Florida; Kemp et al., 2014 and 1830-1940 CE for analysis of the RSL reconstruction; Fig. 8b), which is consistent with results from the U.S. Atlantic coast, where the onset of modern sea-level rise was estimated to occur at $\sim 1870 \mathrm{CE}$ (Kemp et al., 2015). The relatively large uncertainty in constraining the change point at Little Manatee River is a consequence of the low sedimentation rate prior to the 19th century acceleration in sea-level rise. This results in a 1-cm thick slice of sediment representing a longer time interval than at sites where faster rates of GIA result in a correspondingly high rate of sediment accumulation (e.g., Wright et al., 2017).

\subsection{Potential influence of local-scale processes on the relative sea-level reconstruction}

A RSL reconstruction generated from salt-marsh sediment (or indeed any other source of proxy data such as a coral microatoll) represents trends at the location from which the core was collected. Those trends are driven by a combination of local-, regional- and global-scale processes that vary in importance across space and through time. Therefore, a RSL reconstruction can be accurate even if it records trends that are dominated by local-scale drivers such as sediment compaction. A fundamental goal in utilizing RSL reconstructions to generate predictive understanding of physical processes is to untangle the role of driving mechanisms that operate across a range of spatio-temporal scales. We examine the potential influence of local-scale factors on the Little Manatee River RSL reconstruction before drawing comparisons with other sites to garner insight into regional-scale processes.

\subsubsection{Marsh initiation at Little Manatee River}

A prominent feature of our new reconstruction is the sea-level fall at the beginning of the record ( $~ 300$ to $100 \mathrm{BCE}$; Fig. 9). This fall coincides with an environmental and lithological change from a sandy, tidal flat or shallow sub-tidal shoal occupied by Ammobaculites spp. (declining from a maximum of $76 \%$ to $0 \%$ ) to a salt-marsh assemblage in which $A$. mexicana $(56 \%)$ and $A$. inepta (23\%) were the most common species of foraminifera (Fig. 5). We propose that this feature is most likely a local RSL change arising from the salt-marsh's initial colonization of the site through the silting up of a tidal flat (e.g., Redfield, 1965). During this 

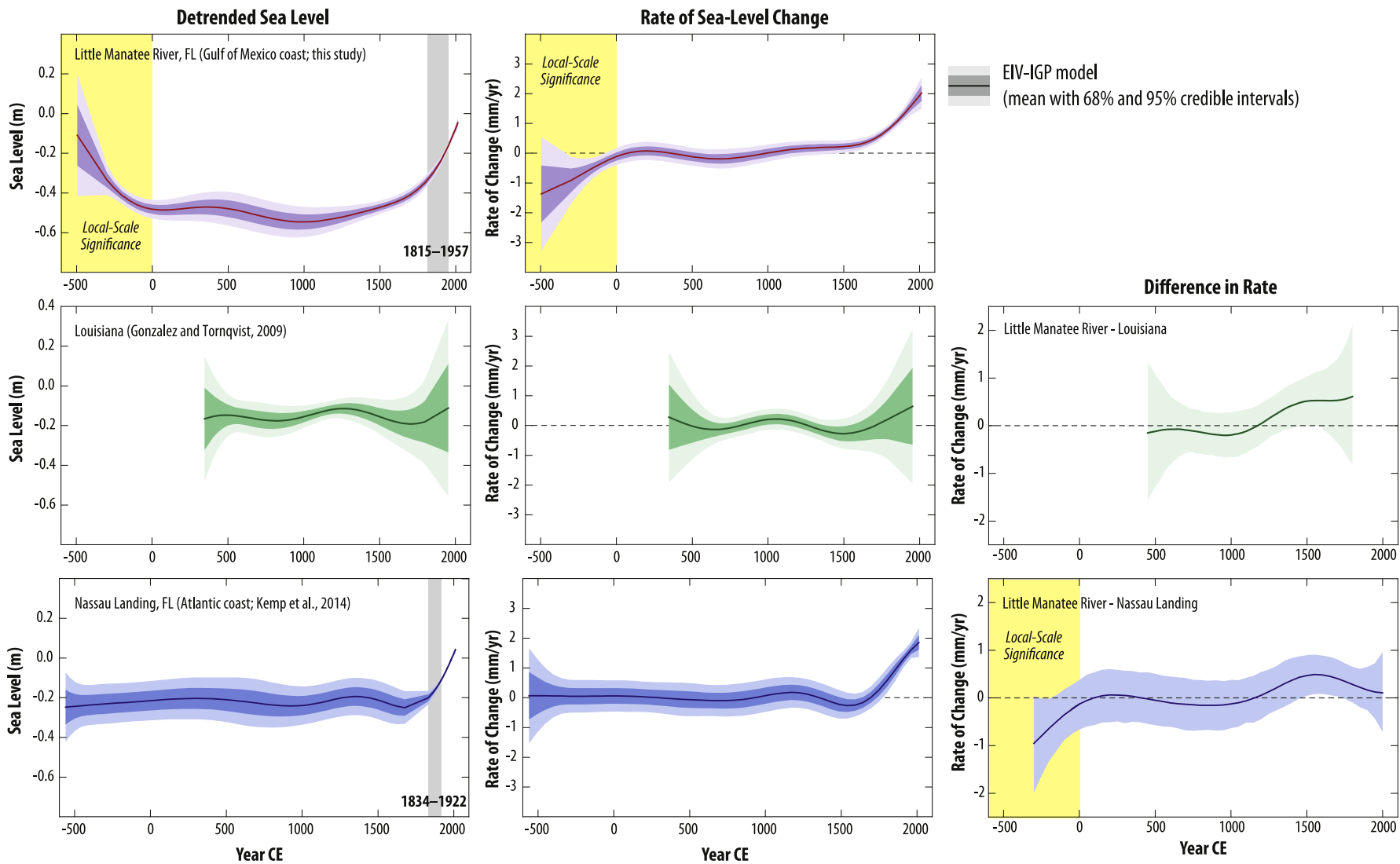

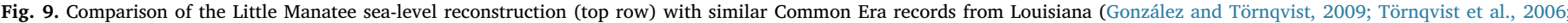

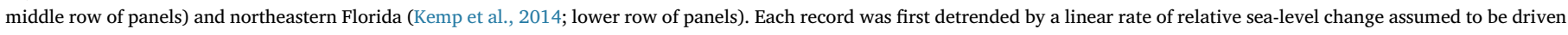

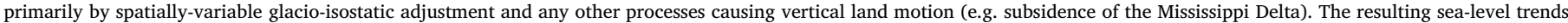

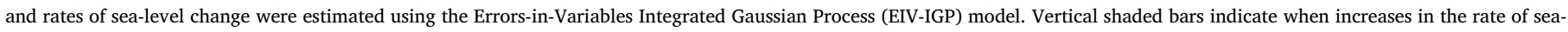

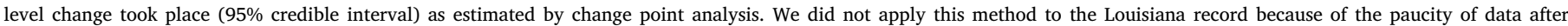

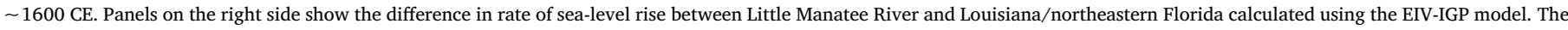

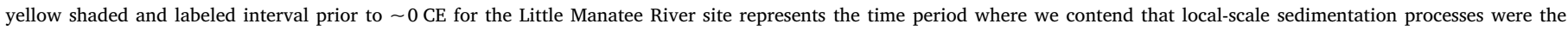
dominant cause of reconstructed RSL trends.

phase, the site experienced sedimentation at a rate that exceeded the rate of regional RSL rise causing emergence and only when a stable, saltmarsh environment was established did the core site become a reliable recorder of regional RSL trends. Our interpretation is further supported by the absence of a sea-level fall of this nature in other RSL reconstructions spanning the same time interval from the North Atlantic Ocean (e.g., Kemp et al., 2015). We therefore propose that the reconstruction prior to $\sim 0 \mathrm{CE}$ should be treated as a record of local-scale processes and should not be taken as representing trends at any location other than the core site.

\subsubsection{Compaction}

Post-depositional lowering of the sediment samples used to reconstruct RSL by mechanical compression (here termed compaction) may lead to an overestimation of the total amount and rates of RSL rise (e.g., Bloom, 1964; Kaye and Barghoorn, 1964). However, continuous sequences of salt-marsh peat overlying a more dense substrate (e.g., sand) do not undergo post-depositional lowering if they remained waterlogged since deposition because of the low bulk-density of peat (e.g., Hijma et al., 2015). We consider the basal sand unit at Little Manatee River to be a substrate that cannot be compacted by the overlying salt-marsh peat and based on observation of modern environments we conclude that the peat unit likely remained water logged due to regular tidal inundation. In the specific case of salt-marsh peat that accumulated in J. roemerianusdominated marshes, a recent study quantified post-depositional lowering using an empirical compaction model (Brain et al., 2015) and concluded that its contribution to reconstructed RSL trends in North Carolina was $<0.03 \mathrm{~m}$. Therefore, we assume that our short $(\sim 1 \mathrm{~m})$ record derived from $J$. roemerianus peat was not subject to the local-scale influence of compaction.

\subsubsection{Influence of fluvial processes}

Our study site at Little Manatee River is located $\sim 5 \mathrm{~km}$ upriver from the outlet into Tampa Bay. Therefore, the time-evolving freshwater discharge may directly cause RSL change at the site (e.g., Meade and Emery, 1971; Gehrels et al., 2004) and influence how far upstream tides (and any RSL "signal") can propagate (e.g., Friedrichs and Aubrey, 1994). In addition, our reconstruction may be indirectly influenced through the effect of freshwater flow on local tidal range (e.g., Jay et al., 2011), where tidal range would be reduced/increased when baseflow is higher/lower. In reconstructing RSL at Little Manatee River using the foraminiferal-based transfer function, we implicitly assumed that tides were stationary for the period under investigation. Although baseflow may have changed through time in response (for example) to wet/dry phases in climate (e.g., Glaser et al., 2013; Stahle et al., 2016), we contend that four lines of evidence suggest that this was not a major influence on our reconstruction. Firstly, there is a high degree of coherence between our reconstruction and existing records from the Atlantic coast of Florida (Kemp et al., 2014) and Louisiana (González and Törnqvist, 2009) as demonstrated by detrended sea-level records that are indistinguishable from one another at the $95 \%$ credible interval (Fig. 9). This suggests that either baseflow was not a significant driver of local-scale RSL trends, or that baseflow changes in each of these three systems were synchronous and of the same magnitude, which we deem unlikely given that the three sites are up to $800 \mathrm{~km}$ apart and located in distinct drainage systems. Secondly, comparison of tidal datums at our site to those at the Port 
Manatee tide gauge (NOAA ID 8726384; Fig. 1) indicate that there is only a $0.06 \mathrm{~m}$ difference in great diurnal tidal range between open bay and estuarine sites, despite their contrasting geomorphic settings and a presumably large difference in the importance of baseflow as an influence on tidal inundation. Thirdly, other sites located similar distances upriver do record centennial-scale RSL variability that was also recorded at the open coast (e.g., Kemp et al., 2013), which suggests the RSL signals are efficiently propagated into estuarine settings even where there is fluvial baseflow. However, caution must be exercised in extrapolating this result to Little Manatee River since estuary dynamics can vary significantly among locations. Fourthly, while Meade and Emery (1971) demonstrated that variations in annual river inflow could account for $21 \%$ of annual RSL variability on the Gulf Coast, they concluded that long-term RSL trends were independent of runoff. Since RSL reconstructions from salt marshes are inherently time-averaged and record RSL trends on timescales of decades and longer, we propose that the empirical study of Meade and Emery (1971) indicates that our reconstruction is not significantly influenced by fluvial processes. Although a body of evidence and geological reasoning indicates that fluvial processes are unlikely to have contributed significantly to the RSL trends reconstructed at Little Manatee River, it is not possible to refute the hypothesis entirely without an additional RSL reconstruction from the open coast near Tampa Bay (in which only local-scale processes could reasonably explain a difference to Little Manatee River) or a proxy reconstruction of river discharge in the same estuary.

\subsection{Common Era sea-level trends in the Gulf of Mexico and North Atlantic Ocean}

González and Törnqvist (2009) produced a detailed Common Era RSL reconstruction from the Mississippi River Delta (Fig. 1) using radiocarbon-dated salt-marsh peat. The data are from three sites and we therefore consider it to represent regional RSL trends from $\sim 600$ to $1600 \mathrm{CE}$. Furthermore, the basal nature of the samples indicates that sediment compaction did not contribute significantly to the reconstructed trends. González and Törnqvist (2009) identified a possible sea-level oscillation at $\sim 1000-1200 \mathrm{CE}$ based on the improved fit offered by a polynomial regression $\left(r^{2}=0.87\right)$ over a linear regression $\left(r^{2}=0.83\right)$ to the mid-points of the discrete RSL reconstructions. To facilitate direct and fair comparison between the Common Era RSL reconstructions from Louisiana and Little Manatee River, we applied the EIV-IGP model to the dataset of González and Törnqvist (2009) combined with RSL reconstructions from Patout Canal reported in Törnqvist et al. (2006). This is the same dataset used in Kopp et al. (2016). The resulting Louisiana RSL reconstruction was corrected for long-term, linear contributions from GIA and delta subsidence that together are estimated to be $0.6 \mathrm{~mm} / \mathrm{yr}$ (González and Törnqvist, 2006; Yu et al., 2012). This analysis (Fig. 9) indicates that the detrended rate of sea-level change in Louisiana increased marginally from zero at $\sim 800 \mathrm{CE}$ to $0.2 \mathrm{~mm} / \mathrm{yr}$ at $\sim 1000 \mathrm{CE}$, but was not distinguishable from zero within the uncertainty (68\% and $95 \%$ credible intervals) for the duration of the reconstruction. In combination with the reconstructed stability from Little Manatee River, we conclude that sea level in the Gulf of Mexico was unlikely to have departed significantly or systematically from the long-term trend driven by GIA/ subsidence during the Common Era, or that any departures were smaller/ shorter than can be resolved with existing salt-marsh records.

On the U.S. Atlantic coast of Florida, Kemp et al. (2014; Fig. 1) reconstructed RSL change during the past $\sim 2600$ years at Nassau Landing and showed that there were no significant, centennial-scale sea-level trends prior to the onset of modern rise at 1834-1922 CE (Fig. 9). This finding was a counter point to reconstructions from further north along the Atlantic coast (e.g., Kemp et al., 2015; Kemp et al., 2011; Kemp et al., 2013) that identified departures from a stable mean. This spatio-temporal pattern was subsequently interpreted as evidence for regional sea-level change driven by dynamic ocean and/or atmospheric processes (e.g., Kopp et al., 2016) because it is broadly similar to model simulations (e.g., Levermann et al., 2005; Yin et al., 2010) and shorter-duration observations of coastal sea level and oceanographic conditions (e.g., Goddard et al., 2015; McCarthy et al., 2015). The Little Manatee River and Nassau Landing sea-level reconstructions are not significantly different to one another (Fig. 9) except at 1500-1700 CE, when sea-level rise at Little Manatee River was $0.03-0.91 \mathrm{~mm} / \mathrm{yr}$ (95\% credible interval) faster than at Nassau Landing (Fig. 9). This difference arises from an apparent slow down at Nassau Landing, rather than an acceleration at Little Manatee River. Some models do predict a modest difference in RSL trends between Florida's Gulf of Mexico and Atlantic Ocean coasts because of ocean dynamic effects. For example, in Coupled Model Intercomparison Project Phase 5 (CMIP5) simulations, Yin (2012) showed that under Representative Concentration Pathways 4.5 and 8.5 there is a small $(<0.1 \mathrm{~m})$, negative dynamic sea-level contribution along the Atlantic coast at $2100 \mathrm{CE}$ and $2300 \mathrm{CE}$, but no change in the Gulf of Mexico. Although this pattern is similar to the reconstructed difference at 1500-1700 CE, we contend that the direction and size of the forcing required to produce it is unrealistic for this time period. It is more likely that the apparent slowing of sea-level rise at Nassau Landing occurs because of the absence of foraminifera in the core used to produce the RSL reconstruction at approximately $1700-1800 \mathrm{CE}$. Therefore, we consider the stability of Common Era sea-level at Little Manatee River and in Louisiana to support the finding of Kemp et al. (2014) that no significant sea-level changes took place on the U.S. Gulf of Mexico and southeastern Atlantic Ocean coasts until the onset of modern sea-level rise.

\section{Conclusions}

Prior to this study a paucity of data prevented the elucidation of Common Era sea-level changes in the Gulf of Mexico. We addressed this knowledge gap by reconstructing $\sim 2000$ years of regional-scale RSL change in western Florida using a transfer function applied to assemblages of foraminifera preserved in a dated core of salt-marsh sediment from Little Manatee River (Tampa Bay, Florida). We combined our proxy reconstruction with a regional tide-gauge record produced from four nearby gauges that span the period from 1913 to $2014 \mathrm{CE}$. We analyzed the combined reconstruction using an EIV-IGP model, which demonstrated that RSL fell between $\sim 350 \mathrm{BCE}$ and $100 \mathrm{BCE}$, before rising continuously until present. We removed a long-term, background rate of RSL rise $(0.3 \mathrm{~mm} / \mathrm{yr}$ driven primarily by GIA) from the reconstruction using the EIV-IGP model to account for covariance in the age and vertical uncertainties induced by this adjustment. Sea level fell between 300 BCE and $100 \mathrm{BCE}$ as a result of local-scale processes and this trend should not be ascribed any significance beyond the core site. After this, sea level did not deviate significantly from zero until $\sim 1500 \mathrm{CE}$ when the rate of sealevel rise started to accelerate until a rate of $2.02 \mathrm{~mm} / \mathrm{yr}$ was achieved in $2014 \mathrm{CE}$. This is the fastest centennial-scale rate recorded during the 2000-year regional-scale reconstruction. We compared our reconstruction from the Little Manatee River to sites in Louisiana (600-1600 CE) on the Gulf of Mexico and to northern Florida (past $\sim 2600$ years) on the U.S. Atlantic coast. These three records show no evidence of significant or systematic sea-level change until the onset of modern sea-level rise, which stands in contrast to similar records from sites further north where centennial-scale deviations from stable sea-level are present in reconstructions derived in a similar fashion from salt-marsh sediment.

Supplementary data to this article can be found online at http://dx. doi.org/10.1016/j.margeo.2017.07.001.

\section{Acknowledgements}

We acknowledge constructive comments from two anonymous reviewers and an internal USGS review from Nicole Khan that helped strengthen this manuscript, as well as comments from David Fastovsky, John King, and Chris Baxter, as part of Gerlach's MSc thesis committee. Jerry Mitrovica provided GIA projections for the Little Manatee River study site. Amanda Chappel provided assistance in the field at Little Manatee River. This work was supported by NSF awards OCE-1458903 and OCE-1458921 to Engelhart and Kemp respectively, a U.S. Fish and Wildlife Service State Wildlife Grant (Award \#F13AF00982) to Moyer, 
Smoak and Engelhart, an Earthwatch Institute IGNITE grant to Engelhart, USDA National Institute of Food and Agriculture, Hatch Funding, and the Rhode Island Agricultural Experimental Station to Engelhart, contribution 5455, and by Teaching and Research Assistantships from the College of the Environment and Life Sciences at the University of Rhode Island to Gerlach. Bernhardt was funded through the USGS Climate and Land Use $R \& D$ program. Any use of trade, firm, or product names is for descriptive purposes only and does not imply endorsement by the U.S. Government. This work is a contribution to IGCP Project 639 "Sea-level change from minutes to millennia", INQUA project CMP1701P, and PALSEA 2.

\section{References}

Adams, P.N., Opdyke, N.D., Jaeger, J.M., 2010. Isostatic uplift driven by karstification and sea-level oscillation: modeling landscape evolution in north Florida. Geology 38, 531-534.

Alexander, T.R., Crook, A.G., 1974. Recent and long-term vegetational changes in southern Florida. In: Gleason, P.J. (Ed.), Environments of South Florida: Present and Past. Miami Geological Society, pp. 61-72.

Bandy, O.L., 1954. Distribution of some shallow-water foraminifera in the Gulf of Mexico. In: Professional Paper. United States Geological Survey, pp. 125-141.

Bandy, O.L., 1956. Ecology of foraminifera in northeastern Gulf of Mexico. In: Professional Paper. United States Geological Survey, pp. 179-204.

Barlow, N.L.M., Shennan, I., Long, A.J., Gehrels, W.R., Saher, M.H., Woodroffe, S.A., Hillier, C., 2013. Salt marshes as late Holocene tide gauges. Glob. Planet. Chang. 106, 90-110.

Birks, H.J.B., 1995. Quantitative palaeoenvironmental reconstructions. In: Maddy, D., Brew, J.S. (Eds.), Statistical Modelling of Quaternary Science Data. Quaternary Research Association, Cambridge, pp. 161-254.

Bloom, A.L., 1964. Peat accumulation and compaction in Connecticut coastal marsh. J. Sediment. Res. 34, 599-603.

Bollhöfer, A., Rosman, K.J.R., 2001. Isotopic source signatures for atmospheric lead: the northern hemisphere. Geochim. Cosmochim. Acta 65, 1727-1740.

Brain, M.J., Kemp, A.C., Horton, B.P., Culver, S.J., Parnell, A.C., Cahill, N., 2015. Quantifying the contribution of sediment compaction to late Holocene salt-marsh sealevel reconstructions, North Carolina, USA. Quat. Res. 83, 41-51.

Breithaupt, J.L., Smoak, J.M., Smith, T.J., Sanders, C.J., 2014. Temporal variability of carbon and nutrient burial, sediment accretion, and mass accumulation over the past century in a carbonate platform mangrove forest of the Florida Everglades. J. Geophys. Res. Biogeo. 119, 2032-2048.

Brooks, G.R., Doyle, L.J., 1998. Recent sedimentary development of Tampa Bay, Florida: a microtidal estuary incised into Tertiary platform carbonates. Estuaries 21, 391-406.

Cahill, N., Kemp, A.C., Horton, B.P., Parnell, A.C., 2015. Modeling sea-level change using errors-in-variables integrated Gaussian processes. Ann. Appl. Stat. 9, 547-571.

Clark, J.A., Lingle, C.S., 1977. Future sea-level changes due to West Antarctic ice sheet fluctuations. Nature 269, 206-209.

Collins, E., Scott, D.B., Gayes, P., Medioli, F., 1995. Foraminifera in Winyah Bay and North Inlet marshes, South Carolina; relationship to local pollution sources. J. Foram. Res. 25, 212-223.

Culver, S.J., Horton, B.P., 2005. Infauna marsh foraminifera from the Outer Banks, North Carolina. J. Foraminifer. Res. 35, 148-170.

Dalca, A.V., Ferrier, K.L., Mitrovica, J.X., Perron, J.T., Milne, G.A., Creveling, J.R., 2013. On postglacial sea level-III. Incorporating sediment redistribution. Geophys. J. Int.

Davis, J.L., Mitrovica, J.X., 1996. Glacial isostatic adjustment and the anomalous tide gauge record of eastern North America. Nature 379, 331-333.

Donnelly, J.P., Cleary, P., Newby, P., Ettinger, R., 2004. Coupling instrumental and geological records of sea-level change: evidence from southern New England of an increase in the rate of sea-level rise in the late 19th century. Geophys. Res. Lett. 31, L05203.

Eleuterius, L., 1975. The life history of the salt marsh rush, Juncus roemerianus. Bull. Torrey. Bot. Club 102, 135-140.

Eleuterius, L., 1976. Vegetative morphology and anatomy of the salt-marsh rush Juncus roemerianus. Gulf Res. Rep. 5, 1-10.

Engelhart, S.E., Horton, B.P., Douglas, B.C., Peltier, W.R., Tornqvist, T.E., 2009. Spatial variability of late Holocene and 20th century sea-level rise along the Atlantic coast of the United States. Geology 37, 1115-1118.

Escobar, J., Whitmore, T.J., Kamenov, G.D., Riedinger-Whitmore, M.A., 2013. Isotope record of anthropogenic lead pollution in lake sediments of Florida, USA. J. Paleolimnol. 49, 237-252.

Ezer, T., Atkinson, L.P., Corlett, W.B., Blanco, J.L., 2013. Gulf Stream's induced sea level rise and variability along the U.S. mid-Atlantic coast. J. Geophys. Res. Oceans 118, 685-697.

Facchetti, S., 1989. Lead in petrol. The isotopic lead experiment. Acc. Chem. Res. 22, 370-374.

Farrell, W.E., Clark, J.A., 1976. On postglacial sea level. Geophys. J. R. Astron. Soc. 46, 647-667.

Fatela, F., Taborda, R., 2002. Confidence limits of species proportions in microfossil assemblages. Mar. Micropaleontol. 45, 169-174.

Friedrichs, C.T., Aubrey, D.G., 1994. Tidal propagation in strongly convergent channels. J. Geophys. Res. Oceans 99, 4431-3336.

Gehrels, W.R., Belknap, D.F., Black, S., Newnham, R.M., 2002. Rapid sea-level rise in the Gulf of Maine, USA, since AD 1800. The Holocene 12, 383-389.
Gehrels, W.R., Milne, G.A., Kirby, J.R., Patterson, R.T., Belknap, D.F., 2004. Late Holocene sea-level changes and isostatic crustal movements in Atlantic Canada. Quat. Int. $120,79-89$.

Gehrels, W.R., Kirby, J.R., Prokoph, A., Newnham, R.M., Achterberg, E.P., Evans, H., Black, S., Scott, D.B., 2005. Onset of recent rapid sea-level rise in the western Atlantic Ocean. Quat. Sci. Rev. 24, 2083-2100.

Gehrels, W.R., Callard, S.L., Moss, P.T., Marshall, W.A., Blaauw, M., Hunter, J., Milton, J.A., Garnett, M.H., 2012. Nineteenth and twentieth century sea-level changes in Tasmania and New Zealand. Earth Planet. Sci. Lett. 315-316, 94-102.

Glaser, P.H., Hansen, B.C.S., Donovan, J.J., Givnish, T.J., Stricker, C.A., Volin, J.C., 2013 Holocene dynamics of the Florida Everglades with respect to climate, dustfall, and tropical storms. Proc. Natl. Acad. Sci. U. S. A. 110, 17211-17216.

Goddard, P.B., Yin, J., Griffies, S.M., Zhang, S., 2015. An extreme event of sea-level rise along the Northeast coast of North America in 2009-2010. Nat. Commun. 6.

Goldstein, S.T., Frey, R.W., 1986. Salt marsh foraminifera, Sapelo Island Georgia. Senckenberg. Marit. 18, 97-121.

Goldstein, S.T., Harben, E.B., 1993. Taphofacies implications of infaunal foraminiferal assemblages in a Georgia salt marsh, Sapelo Island. Micropaleontology 39, 53-62.

Goldstein, S.T., Watkins, G.T., 1998. Elevation and the distribution of salt-marsh Foraminifera, St. Catherine's Island, Georgia; a taphonomic approach. Palaios 13, $570-580$.

Goldstein, S.T., Watkins, G.T., 1999. Taphonomy of salt marsh foraminifera: an example from coastal Georgia. Palaeogeogr. Palaeoclimatol. Palaeoecol. 149, 103-114.

González, J., Törnqvist, T., 2006. Coastal Louisiana in crisis: subsidence or sea level rise Eos 87, 493-498.

González, J.L., Törnqvist, T.E., 2009. A new Late Holocene sea-level record from the Mississippi Delta: evidence for a climate/sea level connection? Quat. Sci. Rev. 28, 1737-1749.

Graney, J.R., Halliday, A.N., Keeler, G.J., Nriagu, J.O., Robbins, J.A., Norton, S.A., 1995 Isotopic record of lead pollution in lake sediments from the northeastern United States. Geochim. Cosmochim. Acta 59, 1715-1728.

Haslett, J., Parnell, A., 2008. A simple monotone process with application to radiocarbondated depth chronologies. J. R. Stat. Soc.: Ser. C: Appl. Stat. 57, 399-418.

Hay, C., Mitrovica, J.X., Gomez, N., Creveling, J.R., Austermann, J., Kopp, R.E., 2014. The sea-level fingerprints of ice-sheet collapse during interglacial periods. Quat. Sci. Rev. 87, 60-69.

Hijma, M.P., Engelhart, S.E., Tornqvist, T.E., Horton, B.P., Hu, P., Hill, D.F., 2015. A protocol for a geological sea-level database. In: Shennan, I., Long, A.J., Horton, B.P. (Eds.), Handbook of Sea-Level Research. John Wiley, Chichester, pp. 536-553.

Hine, A.C., Belknap, D.F., Hutton, J.G., Osking, E.B., Evans, M.W., 1988. Recent geological history and modern sedimentary processes along an incipient, low-energy, epicontinental-sea coastline: northwest Florida. J. Sediment. Res. 58.

Hine, A.C., Brooks, G.R., Davis Jr., R.A., Duncan, D.S., Locker, S.D., Twichell, D.C., Gelfenbaum, G., 2003. The west-central Florida inner shelf and coastal system: a geologic conceptual overview and introduction to the special issue. Mar. Geol. 200, $1-17$.

Hine, A.C., Suthard, B., Locker, S.D., Cunningham, K.J., Duncan, D.S., Evans, M., Morton, R.A., 2009. Karst subbasins and their relation to the transport of tertiary siliciclastic sediments on the Florida platform. In: Swart, P.K., Eberli, G.P., McKenzie, J.A. (Eds.), Perspectives in Sedimentary Geology: A Tribute to the Career of Robert N. Ginsburg, Wiley-Blackwell, pp. 179-197.

Holgate, S.J., Matthews, A., Woodworth, P.L., Rickards, L.J., Tamisiea, M.E., Bradshaw, E., Foden, P.R., Gordon, K.M., Jevrejeva, S., Pugh, J., 2013. New data systems and products at the Permanent Service for Mean Sea Level. J. Coast. Res. 29, 493-504.

Horton, B.P., Edwards, R.J., 2006. Quantifying Holocene Sea-Level Change Using Intertidal Foraminifera: Lessons From the British Isles. 40. Cushman Foundation for Foraminiferal Research, pp. 97 (Special Publication).

Jackson, S.T., Williams, J.W., 2004. Modern analogs in Quaternary paleoecology: here today, gone yesterday, gone tomorrow? Annu. Rev. Earth Planet. Sci. 32, 495-537.

Jay, D.A., Leffler, K., Degens, S., 2011. Long-term evolution of Columbia river tides. J. Waterw. Port Coast. Ocean Eng. 137, 182-191.

Juggins, S., 2011. C2, 1.7.2 ed.

Juggins, S., Birks, H.J.B., 2012. Quantitative environmental reconstructions from biological data. In: Birks, H.J.B., Lotter, A.F., Juggins, S., Smol, J.P. (Eds.), Tracking Environmental Change Using Lake Sediments: Data Handling and Numerical Techniques. Springer, pp. 431-494.

Karegar, M.A., Dixon, T.H., Engelhart, S.E., 2016. Subsidence along the Atlantic Coast of North America: insights from GPS and late Holocene relative sea level data. Geophys. Res. Lett. 43, 3126-3133.

Kaufman, L., Rousseeuw, P.J., 1990. Finding Groups in Data: An Introduction to Cluster Analysis. Wiley-Interscience.

Kaye, C.A., Barghoorn, E.S., 1964. Late Quaternary sea-level change and crustal rise at Boston, Massachusetts, with notes on the autocompaction of peat. Geol. Soc. Am. Bull. 75, 63-80.

Kemp, A.C., Telford, R.J., 2015. Transfer functions. In: Shennan, I., Long, A.J., Horton, B.P. (Eds.), Handbook for Sea-Level Research. Wiley, pp. 470-499.

Kemp, A.C., Horton, B.P., Culver, S.J., Corbett, D.R., van de Plassche, O., Gehrels, W.R., Douglas, B.C., Parnell, A.C., 2009a. Timing and magnitude of recent accelerated sealevel rise (North Carolina, United States). Geology 37, 1035-1038.

Kemp, A.C., Horton, B.P., Culver, S.J., 2009b. Distribution of modern salt-marsh foraminifera in the Albemarle-Pamlico estuarine system of North Carolina, USA: implications for sea-level research. Mar. Micropaleontol. 72, 222-238.

Kemp, A.C., Horton, B., Donnelly, J.P., Mann, M.E., Vermeer, M., Rahmstorf, S., 2011. Climate related sea-level variations over the past two millennia. Proc. Natl. Acad. Sci. 108, 11017-11022.

Kemp, A.C., Sommerfield, C.K., Vane, C.H., Horton, B.P., Chenery, S.R., Anisfeld, S.C., 
Nikitina, D., 2012. Use of lead isotopes for developing chronologies in recent saltmarsh sediments. Quat. Geochronol. 12, 40-49.

Kemp, A.C., Horton, B.P., Vane, C.H., Corbett, D.R., Bernhardt, C.E., Engelhart, S.E., Anisfeld, S.C., Parnell, A.C., Cahill, N., 2013. Sea-level change during the last 2500 years in New Jersey, USA. Quat. Sci. Rev. 81, 90-104.

Kemp, A.C., Bernhardt, C.E., Horton, B.P., Vane, C.H., Peltier, W.R., Hawkes, A.D., Donnelly, J.P., Parnell, A.C., Cahill, N., 2014. Late Holocene sea- and land-level change on the U.S. southeastern Atlantic coast. Mar. Geol. 357, 90-100.

Kemp, A.C., Hawkes, A.D., Donnelly, J.P., Vane, C.H., Horton, B.P., Hill, T.D., Anisfeld, S.C., Parnell, A.C., Cahill, N., 2015. Relative sea-level change in Connecticut (USA) during the last 2200 years. Earth Planet. Sci. Lett. 428, 217-229.

Kemp, A.C., Hill, T.D., Vane, C.H., Cahill, N., Orton, P., Talke, S.A., Parnell, A.C., Sanborn, K., Hartig, E.K., Relative sea-level trends in New York City during the past 1500 years. The Holocene, doi: http://dx.doi.org/10.1177/0959683616683263 (in press).

Kopp, R., Mitrovica, J., Griffies, S., Yin, J., Hay, C., Stouffer, R., 2010. The impact of Greenland melt on local sea levels: a partially coupled analysis of dynamic and static equilibrium effects in idealized water-hosing experiments. Clim. Chang. 103, 619-625.

Kopp, R.E., Kemp, A.C., Bitterman, K., Horton, B.P., Donnelly, J.P., Gehrels, W.R., Hay, C., Mitrovica, J.X., Morrow, E., Rahmstorf, S., 2016. Temperature-driven global sealevel variability in the Common Era. Proc. Natl. Acad. Sci. 113, E1434-E1441.

Krauss, K.W., From, A.S., Doyle, T.W., Doyle, T.J., Barry, M.J., 2011. Sea-level rise and landscape change influence mangrove encroachment onto marsh in the Ten Thousand Islands region of Florida, USA. J. Coast. Conserv. 15, 629-638.

Lankford, R.R., 1959. Distribution and ecology of foraminifera from east Mississippi Delta margin. Am. Assoc. Pet. Geol. Bull. 43, 2068-2099.

Levermann, A., Griesel, A., Hofmann, M., Montoya, M., Rahmstorf, S., 2005. Dynamic sea level changes following changes in the thermohaline circulation. Clim. Dyn. 24, 347-354.

Lima, A.L., Bergquist, B.A., Boyle, E.A., Reuer, M.K., Dudas, F.O., Reddy, C.M., Eglinton, T.I., 2005. High-resolution historical records from Pettaquamscutt River basin sediments: 2. Pb isotopes reveal a potential new stratigraphic marker. Geochim. Cosmochim. Acta 69, 1813-1824.

Livsey, D., Simms, A.R., 2013. Holocene sea-level change derived from microbial mats. Geology 41, 971-974.

Maechler, M., Rousseeuw, P., Struyf, A., Hubert, M., 2005. Cluster Analysis Basics and Extensions.

McCarthy, G.D., Haigh, I.D., Hirschi, J.J.M., Grist, J.P., Smeed, D.A., 2015. Ocean impact on decadal Atlantic climate variability revealed by sea-level observations. Nature 521, 508-510.

Meade, R.H., Emery, K.O., 1971. Sea level as affected by river runoff, eastern United States. Science $173,425-428$.

Mitrovica, J.X., Gomez, N., Morrow, E., Hay, C., Latychev, K., Tamisiea, M.E., 2011. On the robustness of predictions of sea level fingerprints. Geophys. J. Int. 187, 729-742.

Morris, J.T., Sundareshwar, P.V., Nietch, C.T., Kjerfve, B., Cahoon, D.R., 2002. Response of coastal wetlands to rising sea level. Ecology 83, 2869-2877.

Morrison, G., Yates, K.K., 2011. Origin and evolution of Tampa Bay. In: Yates, K.K., Greening, H., Morrison, G. (Eds.), Integrating Science and Resource Management in Tampa Bay. Florida, United States Geological Survey, pp. 37-62.

Morton, J.F., 1980. The Australian pine or beefwood (Casuarina equisetifolia L.) an invasive "weed" tree in Florida. In: Proceedings of the Florida State Horticultural Society, pp. 87-95.

Nicholls, R.J., Hanson, S.E., Lowe, J.A., Warrick, R.A., Lu, X., Long, A.J., 2014. Sea-level scenarios for evaluating coastal impacts. Wiley Interdiscip. Rev. Clim. Chang. 5, $129-150$.

Nriagu, J.O., 1990. The rise and fall of leaded gasoline. Sci. Total Environ. 92, 13-28.

Oksanen, J., Guillaume Blanchet, F., Kindt, R., Legendre, P., Minchin, P.R., O'Hara, R.B., Simpson, G.L., Solymos, P., Stevens, M.H.H., Wagner, H., 2012. Vegan Community Ecology Package, 2.0-5 ed.

Osland, M.J., Enwright, N., Day, R.H., Doyle, T.W., 2013. Winter climate change and coastal wetland foundation species: salt marshes vs. mangrove forests in the southeastern United States. Glob. Chang. Biol. 19, 1482-1494.

Parnell, A.C., Gehrels, W.R., 2015. Using chronological models in late Holocene sea-level reconstructions from saltmarsh sediments. In: Shennan, I., Long, A.J., Horton, B.P. (Eds.), Handbook of Sea-Level Research. John Wiley \& Sons, pp. 500-513.

Parnell, A.C., Buck, C.E., Doan, T.K., 2011. A review of statistical chronology models for high-resolution, proxy-based Holocene palaeoenvironmental reconstruction. Quat. Sci. Rev. 30, 2948-2960.

Peltier, W.R., 1986. Deglaciation-induced vertical motion of the North American continent and transient lower mantle rheology. J. Geophys. Res. 91, 9099-9123.

Peltier, W.R., 1996. Global sea level rise and glacial isostatic adjustment: an analysis of data from the east coast of North America. Geophys. Res. Lett. 23, GL00848.

Peltier, W.R., 2004. Global glacial isostasy and the surface of the ice-age Earth: the ICE5G (VM2) model and GRACE. Annu. Rev. Earth Planet. Sci. 32, 111-149.

Peltier, W.R., Argus, D.F., Drummond, R., 2014. Space geodesy constrains ice-age terminal deglaciation: the ICE-6G_C (VM5a) model. J. Geophys. Res. Solid Earth.

Phleger, F., 1965a. Living foraminifera from coastal marsh, southwestern Florida. Bol. Soc. Geol. Mex. 28, 45-60.

Phleger, F.B., 1965b. Patterns of marsh foraminifera, Galveston Bay, Texas. Limnol. Oceanogr. 10, R169-R184.

Phleger, F.B., 1970. Foraminiferal populations and marine marsh processes. Limnol. Oceanogr. 15, 522-534.

Poag, C.W., 2015. Benthic Foraminifera of the Gulf of Mexico: Distribution, Ecology, Paleoecology. Texas A \& M University Press.

Redfield, A.C., 1965. Ontogeny of a salt marsh estuary. Science 147, 50-55.

Rousseeuw, P., 1987. Silhouettes: a graphical aid to the interpretation and validation of cluster techniques. J. Comput. Appl. Math. 20, 53-65.

Roy, K., Peltier, W.R., 2015. Glacial isostatic adjustment, relative sea level history and mantle viscosity: reconciling relative sea level model predictions for the U.S. East coast with geological constraints. Geophys. J. Int. 201, 1156-1181.

Saintilan, N., Wilson, N.C., Rogers, K., Rajkaran, A., Krauss, K.W., 2014. Mangrove expansion and salt marsh decline at mangrove poleward limits. Glob. Chang. Biol. 20, 147-157.

Scholl, D.W., Stuiver, M., 1967. Recent submergence of southern Florida: a comparison with adjacent coasts and other eustatic data. Geol. Soc. Am. Bull. 78, 437-454.

Scholl, D.W., Craighead, F.C., Stuiver, M., 1969. Florida submergence curve revised: its relation to coastal sedimentation rates. Science 163, 562-564.

Scott, D.B., Medioli, F.S., 1978. Vertical zonations of marsh foraminifera as accurate indicators of former sea levels. Nature 272, 528-531.

Scott, D.B., Suter, J.R., Kosters, E.C., 1991. Marsh foraminifera and arcellaceans of the lower Mississippi Delta - controls on spatial distributions. Micropaleontology 37, 373-392.

Service, U.F.a.W, 1999. South Florida Multi-Species Recovery Plan. Atlanta, Georgia. 2172.

Simpson, G.L., 2012. Analogue methods. In: Birks, H.J.B., Lotter, A.F., Juggins, S., Smol, J.P. (Eds.), Data Handling and Numerical Techniques. Springer, pp. 495-522.

Smith III, T.J., Foster, A.M., Tiling-Range, G., Jones, J.W., 2013. Dynamics of mangrove-marsh ecotones in subtropical coastal wetlands: fire, sea-level rise, and water levels. Fire Ecol. 9, 66-77.

Smoak, J.M., Breithaupt, J.L., Smith, T.J., Sanders, C.J., 2013. Sediment accretion and organic carbon burial relative to sea-level rise and storm events in two mangrove forests in Everglades National Park. Catena 104, 58-66.

Stahle, D.W., Cook, E.R., Burnette, D.J., Villanueva, J., Cerano, J., Burns, J.N., Griffin, D., Cook, B.I., Acuna, R., Torbenson, M.C.A., Szejner, P., Howard, I.M., 2016. The Mexican Drought Atlas: three-ring reconstructions of the soil moisture balance during the late pre-Hispanic, colonial, and modern eras. Quat. Sci. Rev. 149, 34-60.

Törnqvist, T.E., Gonzalez, J.L., Newsom, L.A., van der Borg, K., de Jong, A.F.M., Kurnik, C.W., 2004. Deciphering Holocene sea-level history on the US Gulf Coast: a highresolution record from the Mississippi Delta. Geol. Soc. Am. Bull. 116, 1026-1039.

Törnqvist, T.E., Bick, S.J., van der Borg, K., de Jong, A.F.M., 2006. How stable is the Mississippi Delta? Geology 34, 697-700.

Traverse, A., 2007. Paleopalynology. Springer.

Varekamp, J., Thomas, E., van de Plassche, O., 1992. Relative sea-level rise and climate change over the last 1500 years. Terra Nova 4, 293-304.

Walton, W.R., 1952. Techniques for recognition of living foraminifera. In: Cushman Foundation for Foraminiferal Research. 3. pp. 56-60.

Walton, W., 1964. Ecology of benthonic foraminifera in the Tampa-Sarasota Bay area, Florida. In: Papers in Marine Geology, Shepard Commemorative Volume. MacMillan, New York, pp. 429-454.

Whitmore, T.J., Riedinger-Whitmore, M.A., Smoak, J.M., Kolasa, K.V., Goddard, E.A., Bindler, R., 2008. Arsenic contamination of lake sediments in Florida: evidence of herbicide mobility from watershed soils. J. Paleolimnol. 40, 869-884.

Wojeck, G.A., Nigg, H.N., Braman, R.S., Stamper, J.H., Rouseff, R.L., 1982. Worker exposure to arsenic in Florida grapefruit spray operations. Arch. Environ. Contam. Toxicol. 11, 661-667.

Wolstencroft, M., Shen, Z., Törnqvist, T.E., Milne, G.A., Kulp, M., 2014. Understanding subsidence in the Mississippi Delta region due to sediment, ice, and ocean loading: insights from geophysical modeling. J. Geophys. Res. Solid Earth 119, 3838-3856.

Wright, A.J., Edwards, R.J., van de Plassche, O., 2011. Reassessing transfer-function performance in sea-level reconstruction based on benthic salt-marsh foraminifera from the Atlantic Coast of NE North America. Mar. Micropaleontol. 81, 43-62.

Wright, A.J., Edwards, R.J., van de Plassche, O., Blaauw, M., Parnell, A.C., van der Borg, K., de Jong, A.F.M., Roe, H.M., Selby, K., Black, S., 2017. Quat. Geochronol. 39, $35-67$.

Yin, J., 2012. Century to multi-century sea level rise projections from CMIP5 models. Geophys. Res. Lett. 39, L17709.

Yin, J., Griffies, S.M., Stouffer, R.J., 2010. Spatial variability of sea-level rise in twentyfirst century projections. J. Clim. 23, 4585-4607.

Yu, S.-Y., Törnqvist, T.E., Hu, P., 2012. Quantifying Holocene lithospheric subsidence rates underneath the Mississippi Delta. Earth Planet. Sci. Lett. 331-332, 21-30. 